ROCZNIKI KULTUROZNAWCZE

Tom XI, numer $2 \quad-\quad 2020$

DOI: http://dx.doi.org/10.18290/rkult20112-3

RYSZARD FICEK

\title{
(POST-) MODERNITY AND CHRISTIAN CULTURE IN THE CONTEXT OF THE PERSONALISM OF STEFAN CARDINAL WYSZYŃSKI
}

Mutual tension, especially between the personalistic concept of culture and broadly understood (post) modernity, is inscribed in the specificity of contemporary cultural reality, which is rooted in the formation of the Christian vision of earthly reality. ${ }^{1}$ However, the severe conflict between Catholicism and "modernity" deepened in the modern period (the Renaissance, especially the age of Enlightenment). ${ }^{2}$ The above analyzes of these issues in the light of the personalistic vision presented by Cardinal Stefan Wyszyński will, therefore, be the main task of these considerations. At the same time, it is oriented towards further in-depth reflection and dialogue aimed at a better understanding of the issues discussed.

RyszARD FiCEK, PhD - Priest of the diocese of Rockville Center, NY, the moral theologian and political scientist, a former lecturer of the Jordan University College in Morogoro (Tanzania), specializing in the moral theology, church history, and international relations; address for correspondence - e-mail: rficek@optonline.net. ORCID: https://orcid.org/0000-0001-5238-6767.

${ }^{1}$ Undoubtedly, the discourse around (post) modernism is closely related to the discourse around (post) modernity. According to the already standard distinctions, it is assumed that modernity and postmodernity are terms of entire cultural epochs in the history of the West. Meanwhile, modernism and postmodernism are the names of the Wittgensteinian "family similarities" or kinships of ethical, aesthetic, and worldview theories and beliefs accompanying modernity (modernism) and postmodernity (postmodernism). Cf. Matei Calinescu, Five Faces of Modernity: Modernism, Avant-Garde, Decadence, Kitsch, and Postmodernism (Durham, NC: Duke University Press, 1987), 14-93.

${ }^{2}$ However, upon closer inspection, things get much more complicated. At this point, a question immediately arises about the temporal and content scope of both "modernity" and "postmodernity." Opinions on this matter are divided. The prevailing view, however, equates the birth of modernity with the rise of capitalism and the dynamic process of modernization of the Western world that began in the seventeenth century and continued until the end of the $1960 \mathrm{~s}$. In this perspective, "postmodernity" would cover the period from the 1960s to today. However, its symptoms would be visible much earlier. Cf. Andreas HuYSSEN, After the Great Divide: Modernism, Mass Culture, Postmodernism (New York: Macmillan, 1988), 3-64. 


\section{1. (POST-) MODERNISM: THE UNBEARABLE WEIGHTLESSNESS OF BEING}

In the context of the above analyzes, all the theories that accompanied the modernization process of the West, supporting it "ideologically," providing legitimacy, and philosophical justification, as well as stimulating its dynamics and setting directions for action, should be considered as modernist. In fact, the issues that, in expressing a rebellion against them, referred to premises shared with the objects of their attack. In this perspective, the Enlightenment and Positivism rise to the rank of classically "modernist" philosophical and worldview options. Therefore, the Romanticist's thought is an example of an inter-modernist reaction to the extreme solutions promoted by them. ${ }^{3}$

Nevertheless, it seems that Max Weber's sociology provides the most convincing characteristics of the processes related to "modernity." Its crucial thesis for understanding the cultural fate of the West was the desire to disenchant the world, which took place in Europe during the transition from traditional to modern society. ${ }^{4}$

In carrying out this task, the rationalization of many spheres of life turned out to be extremely helpful. One of the essential features of cultural rationalization was the breakdown of the "substantional reason" expressed by religion and metaphysics into three autonomous spheres. They are science, morality, and art. However, they diversified as the world-uniting concepts of religion and metaphysics fell apart. From the eighteenth century on, the problems inherited from these older worldview systems were organized to fit into specific categories of significance: truth, normative rightness, authenticity, and beauty. These could then be considered as questions of knowledge, justice, and morals, or taste. Academic dissertations, theories of morality, jurisprudence, as well as art production and art criticism, could, in turn, be institutionalized. ${ }^{5}$

In other words, rationalization, as understood in the Weberian way, was associated with the disintegration of the homogeneous form of culture typi-

\footnotetext{
${ }^{3}$ Cf. CAlinescu, Five Faces of Modernity, 95-148.

${ }^{4}$ Cf. Max Weber, "Nauka jako zawód i powołanie," trans. Piotr Egel, in Max Weber, Polityka jako zawód i powotanie, wybrał, opracował i wstępem opatrzył [selected, compiled and edited with an introduction by] Marek Dębski (Warszawa: Niezależna Oficyna Wydawnicza, 1989), 47-49.

${ }^{5}$ Cf. Jürgen Habermas, "Modernizm — niedopełniony projekt," trans. Adam Sobota, Odra 1987, no. 7-8: 47.
} 
cal of traditional societies. It consisted of the establishment of the spheres of material and production activity and modern bureaucracy, autonomous to worldview values (mainly religious). These spheres, together with material and production activities, previously constituted a whole subordinated to the implementation of appropriate cultural, mythical, or religious values. From that moment on, science began to orientate itself towards truth, morality as well as the law towards normative equity, and art towards authenticity. ${ }^{6}$

The belief in the beneficial effects of the conquest of nature and the strengthening of the productive potential of society was the order of the day. The ideology of work, production, and profit was the motivational base for the continual expansion of the capitalist social system. On the political level, modernity has been expressed in the organization of political life by parties acting on behalf of certain classes or social groups and vigorously fighting for power within the democratic political game.

Nevertheless, "modernity," or the so-called "modernist project" (a term coined by Jürgen Habermas ${ }^{7}$ ), had utterly failed the hopes placed on it. Why? The answer can be found in the depiction of "modernism," which consists of the following postmodern anti. ${ }^{8}$

\footnotetext{
${ }^{6}$ In each of these areas, the Enlightenment category of progress has been established for good. From the perspective of the ideology of progress, it was only a matter of time when science would recognize the ultimate truth about the natural and social world, morality and law would finally discover the absolute rightness (Norm) resulting only from reason, and not the result of religious persuasion, and art would finally express the full truth about man penetrating the most resonant spheres of his psyche. This ideology was extended, however, to the entire culture. The reason was to introduce human life on the path of constant self-improvement, uprooting old superstitions. Science - the flywheel of modernity - was harnessed to the chariot of progress, providing knowledge that, on the one hand, it strengthened the technical and technological potential of humanity (natural sciences). On the other, it established rational standards of social life (humanities and social sciences), contributing to the introduction of innovations for educational, judicial, or psychotherapeutic practice. Cf. ibid, 47-52.

${ }^{7}$ Cf. ibid, 45-53.

${ }^{8}$ Postmodern discourse, however, is broadly based on the following principles: (1) First, antihistoricism, which is the rejection (condemnation) of tradition and, associated with it, historical thinking. Although the "historical trips" of postmodernists go back to the times of Plato and Aristotle (understood in Plato's way of thinking), the most criticized is Descartes and the extremely rationalist current of post-Cartesian thought, as well as the earlier historic utopism and later ideologism, which became the principles of (social) philosophy in the Enlightenment - from its cognitive and anthropological optimism and its teleological historiosophy, according to which history has a transcendent sense-goal - that is why in the writings of postmodernists we find the most anti-Enlightenment rhetoric. (2) Secondly, anti-essentialism (anti-fundamentalism or antifoundationalism), which consists in rejecting the modernist dogma of the existence of the socalled "unshakable principles" or the so-called "permanent"-ontological, cognitive, moral, artistic, and religious. The belief in the existence of such "constants" is often called by post-
} 
In this context, there has been a radical break between "modernity" and Catholicism. Catholicism itself, in the face of the emerging "modernity," began to be perceived as a kind of a "scarecrow" that-supposedly-had restrained new ideas and cultural undertakings. No wonder then that in such a situation, the same "modernity" was characterized by quite ostentatious anti-Catholicism. After the turbulent social and political perturbations of Europe at that time and the related Protestant revolt by Martin Luther, there were drastic divisions in the heart of Western Christianity. ${ }^{9}$

The secularization of broadly understood social life began to play an increasingly important role. The "secularism" of that time, however, was not only a functional equivalent of religion. They were asking difficult questions that were not answered, stimulated new ways of thinking. "Modern" or secular content arose as a result of the formal and functional "re-seizure" of previous "positions" conveyed by religious tradition. In this sense, "modernity" meant a kind of "second overcoming of Gnosticism," reflecting the

modernists the "error of centrism": logos-centrism, theo-centrism, or-as in feminism - phalluscentrism. Those mentioned above "unshakable principles" were treated in modernism as universal model causes of human civilization and cultural activities, which led to the totalization and mechanization of social life and the alienation of its fundamental structures; the so-called judgmental philosophies that arose from the spirit of modernism could only create nightmarish Leviathan states (K. Popper). Antisessentialism is generally expressed in the catchy psychological "obituary" presented in popular slogans heralding the coming of the era of the so-called "death" of culture-God, man, science, morality, or art. The word "death" in this case means that the traditional ideas and concepts of God, man, and morality are logically "dead," that is, they can no longer generate culture. In other words, humanity is in the phase of the so-called "exhaustion of opportunities" and thus reached the end of its own history. (3) Third, anti-discriminatoryism (anti-binarism, anti-dualism, anti-positionism), that is, the negation of the modernist myth of oppositions, e.g., subject-object; mind — body; reason - feelings; cognition — action; truth false; good evil; beauty ugliness. According to postmodernists, the oppositional way of thinking "obsession with binarism"- leads to the emergence of undecidable problems in the culture, e.g., "mind-body problem" or the question of the definition of truth in culture, and results in the petrification of human life, and thus unjustified privileging of recognized ideals (values), and condemning others, i.e., intolerance. Cf. Henryk KIEREŚ, "Postmodernizm: rzeczywistość czy kreacja," in Poznanie bytów, czy ustalenie sensów? Zadania wspótczesnej metafizyki 1, ed. Andrzej Maryniarczyk \& Maria Joanna Gądek (Lublin: Polskie Towarzystwo Tomasza z Akwinu, Lublin, 2016), 177-179.

${ }^{9}$ As already mentioned, practically from the beginning of the $16^{\text {th }}$ century, the ideas of the Renaissance and Reformation began to exert a significant influence on Christianity. Later, the $17^{\text {th }}$-century philosophy of nature and the $18^{\text {th }}$-century Enlightenment formulated fundamental theses of what Bruno Latour calls "the constitution of modernity." Projects such as nature domination and social emancipation were no longer covered by the guarantees of divine transcendence endorsed by the Church's Magisterium. However, the apparent disagreement will emerge quite gradually. Cf. Bruno Latour, We Have Never Been Modern (Cambridge, MA: Harvard University Press, 1993), 34. 
repeated translation of contemporary philosophical and theological themes into the prose of everyday life. ${ }^{10}$

This is how the main features of the "modern" cultural and civilizational formation can be generally characterized, which, especially in this context, seem not too consistent with the personalistic idea of the human person represented by Wyszyński.

First of all, his concept strongly underlined the transcendence of man in the dimension of a person, his mental powers, as well as his activity in shaping the broadly understood culture. According to the Primate, hence, the human person-as a subjective and self-existing "I" given to us in experience from the existential side-forms for himself a specific individual nature. Therefore, the active function of the inner spiritual "I" indicates his transcendence towards the natural world. Also, features such as intellectual cognition, love, and freedom reveal the transcendence as well as the dignity of man in relation to his nature.

Moreover, the acts of cognition, love, and freedom interact with each other, and, as a result, cognition is free, selective, emerging under the influence of love. So, personal love is understood in the spiritual dimension as a free and permanent act of will. In other words, freedom is rational. It is guided by rational will, that is, responsible love. Such fusion of intellectual cognition, rational wanting-love, and freedom of action fundamentally distinguishes a human being from other beings. ${ }^{11}$

Consequently, the synthesis of intellectual cognition, spiritual love, and rational, responsible freedom that appears in a personal action is the basis for which we call ourselves "I," experiencing ourselves as a real subject. In this sense, there are three other features of the personal being related to human social life: the subjectivity of law, ontic completeness, and dignity, which condition each other, presupposing intellectual cognition, spiritual love, and responsible freedom.

That is why the human person is not the result of the "organized matter" but a self-existing subject and agent: both in his actions and his own-to some extent-nature. Authentic personalism, thus, is characterized by the fact that

${ }^{10}$ Cf. Amos Funkenstein, Theology and the Scientific Imagination from the Middle Ages to the Seventeenth Century (Princeton, NJ: Princeton University Press, 1986), 1-22, 57-71; Hans Blumenberg, The Legitimacy of the Modern Age (Studies in Contemporary German Social Thought), trans. Robert M. Wallace (Cambridge, MA: MIT Press, 1983), 125-266.

${ }^{11}$ Cf. Ryszard Ficek, Christians in Socio-Political Life: An Applied Analysis of the Theological Anthropology of Cardinal Stefan Wyszyński, Primate of Poland (Torun: Wydawnictwo Adam Marszałek, 2020), 23-38. 
it protects the existential integrity and dignity of the human person when it speaks of his relation to society. Interpersonal communication, though, occurs in a variety of ways, but most often through acts of love. Man is a "potentialized personality," which is actualized in various types of socio-political and economic life: family, Nation, the international community, etc. ${ }^{12}$

However, the social character of a man is not synonymous with the relational concept of the person. Man is "being in himself" and "being for himself." He has ontic integrity and, therefore, is not constituted by social relations. In other words, it does not gain his existence from the natural world or society. In this sense, social life does not create man, but completes him, develops him. Furthermore, man obtains his personal fullness only in the supernatural dimension. ${ }^{13}$

In turn, "postmodernism" can be treated as a philosophical and worldview expression of "postmodernity," which stimulates it and is also stimulated by it. However, its features are best reflected in the postmodern discourse itself. At this point, it should be added that there is a far-reaching agreement that the postmodern era must be linked to the advent of post-industrial societies. It concerns post-industrial societies, and according to the classic analysis of post-industrialism by Daniel Bell, the production paradigm was substituted by the consumption paradigm, the information civilization replaced the civilization of coal and steel. The state was getting rid of its economic power more and more in favor of large multinational corporations; capital becomes hugely mobile. There is an acceleration of the coupling processes between production and science, the transition from the economy of goods production to the economy of services. The class of professional service and administration workers and technocrats is becoming dominant in society; theoretical knowledge - both in the natural and social sciences - becomes the primary source of social innovation. ${ }^{14}$

The social obligation now is not so much work as consumption. At the same time, as Jean Baudrillard claims, it is not so much the consumption of material goods as, above all, signs and messages produced in vast amounts by modern media. The inflationary (obscene) overproduction of messages is ac-

${ }^{12}$ Cf. Czesław Bartnik, "Zarys myśli teologicznej Kardynała Wyszyńskiego," Ateneum Kaptańskie 73 (1981), vol. 97: 224-228.

${ }^{13}$ Cf. Stanisław Fel \& Marek WódKa (eds.), Kardynat Stefan Wyszyński (1901-1981). Myśl spoteczna (Lublin: Wydawnictwo KUL, 2017).

${ }^{14}$ Cf. Daniel Bell, The Coming of Post-Industrial Society: A Venture in Social Forecasting (New York: Basic Books, 1973), 47-118. 
companied by the deepening indifference of the audience, unable to absorb them anymore. People inhabit an increasingly artificial reality of simulacra, understood as images and signs that "emancipated from their meaning" and became a "copy without the original," "A map without territory," a hyperspace composed of information whirling faster and faster. Their participation becomes a mosaic (patchwork) culture, fragmented, incoherent, and decentralized. ${ }^{15}$

It has its direct reference to the postmodern vision of culture. Indeed, postmodernism treats culture functionally and utilitarily. ${ }^{16}$ Consequently, an essential feature of the postmodern conception of culture is its depersonalization, i.e., complete detachment from the concept of a human being as a person. If the existence of human nature is questioned, culture is often dehumanized in practical terms. Its goal is no longer the good of the human being-the person, but the expected short-term benefits (consumerism, primitivism, functionalism, excess of form over content, irrationalism, etc.).

Therefore, the personalistic vision of the human person seems to be the right answer to the problems of modern man. The subjective, personal, and spiritual approach to man can be contrasted with extreme scientism, nihilism, as well as with the objective and utilitarian use of man, whether for profit or pleasure. Personalism is opposed to such views. Primate Wyszyński states that man treated as an object, product, thing, tool, and means is used against his nature and dignity. ${ }^{17}$

${ }^{15}$ Cf. Jean Baudrillard, Consumer Society: Myths and Structures (London: Sage Publications, 1998), 49-185.

${ }^{16}$ This is why, for example, Richard Rorty gives up the cognitive and theoretical goals of culture and states that philosophy has ceased to play the role of the "backbone" and "overseer" of the entire culture. Culture - in his opinion - is not based on "eternal standards" as there are no permanent and universal criteria of truth, goodness, or beauty. Not philosophy and epistemology seem to be essential parts of culture, but the pragmatics of human life. Culture is "a multitude of cognitive claims," its paradigm is philosophical, aesthetic, social, political, and ideological pluralism. Therefore, Rorty opted for ethnocentrism in understanding culture, recognizing the significant dependence of human views on historical-time, social, political, etc. At the same time, however, despite his cultural ethnocentrism, he considered Western liberal culture to be the best and, to some extent, applicable on a global scale. This position is logically inconsistent and selfcontradictory. Some commentators of the American neo-pragmatist repeal the above objection, claiming that Rorty ignored the epistemological value of individual cultures (including liberal ones), and only had in mind the fact that Western culture is relatively the best in ethical and political terms. Such an apologetic explanation goes along with the line of pragmatism, as it recognizes the inferiority of truth to good and immediate political benefits. Cf. Richard RoRTY, Filozofia a zwierciadło natury, trans. Michał Szczubialko (Warszawa: Wydawnictwo Spacja, 1994), 239-283; IDEM, Objectivity, Relativism and Truth. Philosophical Papers (Cambridge, MA: Cambridge University Press, 1991), 113-161; 258-263.

${ }^{17}$ Cf. BARTNiK, , "Zarys myśli teologicznej," 225-226. 
In his opinion, being personal may be a way to get to know oneself and overcome the deepening crisis of identity. Emphasizing the dignity of the human person and caring for the common good is an attempt to get out of the civilization of excess and shortage - the fortresses of the rich and the excluded ghettos. Maximizing profit without maximizing the good has no meaning or benefit to people. ${ }^{18}$

In other words, culture understood in (post) modernist terms seems to be totally depersonalized. Only the personalistic dimension of culture, emphasizing the protection of the human person, his dignity, and rights, can be a way to stop the phenomenon of infantilization of culture, and thus of man. Establishing personal relationships and caring for others may halt the phenomenon of the breakdown of interpersonal ties, loneliness, and loss of sense of security, as well as may improve the deteriorating spiritual condition of contemporary people.

Consequently, personalism, as understood by Wyszyński, is expressed primarily in the predominance of ethics over technology, the priority of a person over a thing, the importance of "being over having," as well as in the primacy of mercy over justice. In this sense, the "progressive civilization of death," where man usurps the right and the right to interfere in the process of conception, development, and termination of human life, practically at any moment, can be stopped and replaced by the civilization of love. Love is the love of life, protecting it from conception until natural death; it is caring for one's neighbor in terms of his goodness, both temporal and eternal. ${ }^{19}$

Summing up, personalism, as understood by Wyszyński, is expressed primarily in the "civilization of love." In this sense, the liberal "civilization of death," where man usurps the right to interfere in the process of conception, development, as well as the termination of human life, can be brought to a halt and replaced by the civilization of love and mercy. Such merciful and empathetic love is comprehended as a passion of life, protecting it from the moment of its conception until natural death as well as caring for one's neighbor in terms of his goodness, both temporal and eternal.

${ }^{18}$ Cf. Stefan WyszyŃSKI, "W godzinie wielkiego rachunku sumienia. Ołtarzew 2.10.1980," in Kościót w stużbie Narodu. Nauczanie Prymasa Polski czasu odnowy w Polsce sierpień 1980 maj 1981 (Rzym: Ośrodek «Corda Cordi» i Delegatury Biura Prasowego Episkopatu Polski w Rzymie, 1981), 73-77.

${ }^{19}$ Cf. IDEM, "W obronie życia Polaków. Warszawa-Leszno 9.03.1975," in Stefan WYsZYŃsKI, Prymat człowieka w tadzie społecznym (Londyn: Odnowa, 1976), 184-188. 


\section{CULTURE AS AN ANTHROPOLOGICAL AND THEOLOGICAL ISSUE}

According to the personalistic vision of culture presented by Wyszyński, man as a homo artifex is its subject, purpose, as well as meaning, always displayed in the creative-salvific perspective. No wonder then that the primate's understanding of culture aroused quite a lot of controversy, especially in the context of contemporary attitude towards the world described as modernism or postmodernism.

The tendency that exists between the personalistic concept of culture and broadly understood (post) modernity is inscribed in the specificity of contemporary cultural reality, which is rooted in the initial period of shaping the Christian vision of earthly reality. Moreover, the tensions between Catholicism and "modernity" that have arisen over the centuries are undoubtedly deep and lasting. Therefore, the above article fits into the context of the debate on the position and role of the Christian understanding of culture in the contemporary world in relation to the Catholic tradition and its place in the (post) modern world. ${ }^{20}$

Regression and inertia in the Christian tradition regarding an apparent attitude towards the liberal, collectivist cultural tradition, or the so-called contemporary (post) modern culture is not a new phenomenon. Nor did it arise as a result of reforms initiated by the Second Vatican Council, or the implementation of their ideas in the contemporary reality of the post-Conciliar Church. Nevertheless, Vaticanum II is widely regarded as an epochmaking event that has set the direction and priorities for modern Christian involvement in the entire sphere of culture. ${ }^{21}$

\footnotetext{
${ }^{20}$ Cf. Jan Zbigniew CELEJ, Kultura chrześcijańska dusza narodu (Warszawa: Wydawnictwo Sióstr Loretanek, 1995), 34-57.

${ }^{21}$ Historically, the position of the Church's Magisterium on the complex issue of the so-called "modernity" can be traced in many papal encyclicals from the nineteenth and early twentieth century. Popes of this era dealt with the topic of modernism understood as a diverse constellation of ideas concerning primarily the relationship between philosophy and theology, especially the issue of natural (philosophical) theology relating to the subjective experience of faith and the authority of Christian tradition. However, they were afraid of negative implications for the Church regarding the concept of the common good, fundamental principles conditioning the functioning of modern political philosophies, both in the liberal and socialist version. It is particularly evident in the encyclical Rerum Novarum of Pope Leo XIII, as well as in many other declarations of the Holy See from the turn of the eighteenth and nineteenth centuries, which appeared in the context of Catholics' persecution in then France and other countries. (cf. PIUS VI, Encyclical Charitas (1791), in The Papal Encyclicals 1740-1878 (New York: McGrath, 1981),
} 
Virtually, all of the then official statements of the Holy See opposed the basic premise of the Enlightenment philosophy emphasizing that faith is merely a matter of submitting to the experience of reason. In this wayrooted in the concept of Enlightenment naturalism by Jean-Jacques Rousseau, or materialist Marxist philosophy, the idea emphasizing that the cause of all social injustice are socio-political and economic institutions, but not original sin and its vices - it has become an essential determinant of contemporary culture. It is also associated with the liberal concept of the primacy of individual freedom as an indicator of the modern - too anthropological and theological-vision of the human person.

In this context, the official statements of the Holy See show an awareness of the cultural situation in which modern theology and political philosophy operate. However, this did not lead to the development of a systematic critique of "contemporary culture," especially in the face of the challenges posed to Christianity by various intellectual traditions such as radical liberalism, Heglism, Marxism (especially representatives of the "Frankfurt School"), as well as concepts derived from-already mentioned-Enlightenment rationalism or philosophy of Friedrich Nietzsche. ${ }^{22}$

In this context, it is worth emphasizing the most controversial ideas of philosophical and theological nature that inspired the Council Fathers, including Wyszyński. Nevertheless, they had a significant impact on the development of essential determinants defining contemporary dialogue with culture. Indeed, the analysis of this legacy must take into account the broader historical as well as the doctrinal context. The Christian vision of commitment to culture is also part of the reality of the philosophical and

177-178; Gregory XVI, Encyclical Mirari Vos (1832), in The Papal Encyclicals 1740-1878, 235-243; Pius IX, Encyclical Qui Pluribus (1846), in The Papal Encyclicals 1740-1878, 275277; Leo XIII, Encyclical Inscrutabili Dei Consilio, in Actes de Leon XllI, vol. I (Paris: Maison de la Bonne Presse, 1903), 8-25; IDEM, Encyclical Quod Apostolica Muneris (1878), in Actes de Leon XllI, vol. 1, 26-41; IDEM, Encyclical Nobilissima Gallorum Gens (1884), in Actes de Leon XIII, vol. II (Pairs: Maison de la Bonne Presse, 1903), 26-41; Peter HenricI, "Modernity and Christianity." Communio 17 (1990), no. 2: 141-152).

22 "Some proclaim man as a god for himself. They proliferate [human] laws at the expense of God himself and the weaker fellowman, at the expense of society and the state. Everything is to bow to man. There are no restrictions. They subject everything to the highest and irrevocable judgment of man: they proclaim his moral freedom, freedom from all social obligations. They only recognize private morality for personal use. Man can do what he likes - morality is his own thing. They do likewise with God. Religion is also an individual thing of man. Perfection and striving for God have no social significance. The supreme goal of man is his temporal happiness. For this purpose, you can strive for all the ways, because here no moral principles bind." Stefan WyszyŃski, Miłość i sprawiedliwość społeczna (Poznań: Pallottinum, 1993), 46. 
theological discourse shaping the specificity and importance of culture, especially concerning the moral formation of modern man.

As Wyszyński pointed out: "The temporal goal is indirect to the final goal. Man's earthly purpose, the highest in his order, is the perfection of earthly life. All life tasks that create our personal, family, professional, social, national, economic, political as well as religious life come together in it. Striving to achieve this goal is a moral duty of man as well as responsibility towards society and God. To accomplish this goal, we have the full harmony of the natural gifts received from nature, community, and God, the Creator of nature. (...) Experience teaches that temporal goals, even if we would have fully achieved the perfection of earthly life, are not able to fulfill all desires of the human soul. It is much more abundant in its endeavors. Created in God's image and likeness, man only takes a rest in God. Hence, the ultimate goal of man is to connect with God in eternal happiness. We strive to accomplish it by fulfilling God's commandments and by sanctifying ourselves. Thus God's will is your sanctification (1 Thes. 4, 3)." ${ }^{23}$

\section{THE NEED FOR A THEOLOGICAL HERMENEUTIC}

The sensitive issue in the current debate about Christian culture in the context of (post) modernity is the status of reconstructive hermeneutical theories. The hallmark of such ideas is the claim that texts have a stable and determinate meaning that may be recovered and represented by an interpreter (even centuries or millennia later) after proper philological and socio-cultural analysis. Traditionally, this understanding was based, even if not always explicitly, on the fundamental unity of human nature perduring across history.

An essential but crucial issue in the current debate about Christian culture in the context of (post)-modernity is the status of reconstructive hermeneutic theories. A hallmark of such approaches is the assertion that texts have a stable and specific meaning that can be recreated and re-presented by an interpreter (even after centuries or millennia) after an appropriate philological and socio-cultural analysis. Traditionally, this understanding has been based, even if not always explicitly, on the fundamental unity of human nature throughout history. However, if postmodernity affects one's know-

\footnotetext{
${ }^{23}$ Miłość i sprawiedliwość, 50.
} 
ledge of the truth, then it also influences, necessarily and forcefully, one's understanding and comprehension of textual interpretation. Hence, any hermeneutical theory is a logical corollary of one's (non)-foundationalist option. However, the crux of the matter involves determining interpretative appropriateness in light of our contemporary situation.

The shared ontology or common nature, though, was based on a recoverable and representable textual meaning. However, if, as postmodernity claims, there is no fundamental human nature, no common essence, no transcendental consciousness, or no stable structure of cognition, then one cannot speak of a standard matrix of reconstructive thought. Without some universal nature "rooting," an objectivist hermeneutic, stable and reproducible textual content cannot be logically defended.

Reconstructive understanding is, therefore, the basis of the form/content or context/content distinctions so popular in theology and other disciplines. This approach assumes that one may distinguish the meaning or content of a text from its specific context or form. It is about recognizing that authors can say the same thing (with nuance, of course) under different expressions, systems, and schemes. However, it is not about saying that language is just a shell; it is the distinction between meaning and expression. The difference between form/content is based on the interpreter's ability to understand the "foreign" text, recreate its sense (using appropriate tools), and then reformulate the meaning in a different form or context. The defined meaning will be preserved even if the substance is re-expressed in another conceptual system. ${ }^{24}$

Postmodern hermeneutics, of course, finds fault with all of the preceding. Reconstructive interpretation, like the realist and referential notion of truth,

${ }^{24}$ Theologically, the context/meaning distinction has its roots in the concepts of HenriDominique Gardeil, Henri Bouillard, Ives Congar, Marie-Dominique Chenu, Henri de Lubac, and Hans Urs von Balthasar. This was especially helpful in trying to free theology from the unequivocal method imposed by Aeterni Patris. By emphasizing the stability of the content in various conceptual forms, theologians could rightly argue for the material transmission of the same deposit of faith while insisting on a new dialogue with phenomenology, Marxism, and transcendental thought. Stable and enduring doctrinal importance has been combined with a certain degree of fluidity and flexibility in formulation and expression. Ultimately, this point of view was officially sanctioned by the Second Vatican Council and subsequent documents of the Magisterium. It was also approved by Lonergan, Rahner, Kasper and Dulles. Cf. Bernard Lonergan, Doctrinal Pluralism (Milwaukee, WI: Marquette University Press, 1971), 10-11, 44-45; IDEM., Method in Theology (London: Longman and Todd, 1971), 324-26; Walter KASPER, Theology and Church. Translated by M. Kohl (New York: Crossroad, 1992), 144-145; Avery Dulles, The Craft of Theology (New York: Crossroad, 1992), 108. 
is inexorably linked to a discredited and truncated ontology. ${ }^{25}$ Heidegger has deconstructed any idea of perduring nature or transcendental structure by unveiling the epistemologically buried horizon of historicity enveloping all being and thought. He has revealed the depths to which Dasein is always already constituted and constructed by preunderstanding, linguisticality, and finitude. Gadamer has extended the Heideggerian project to interpretative theory, showing how the previously forgotten "worldhood of the world" and the fundamental matrix of temporality are now essentially constitutive of all textual readings. One can no longer speak of reconstructive understanding. A different kind of continuity than the type established by "Romantic" hermeneutics must now be found. ${ }^{26}$

Of course, postmodern hermeneutics finds flaws in all of the preceding. Reconstructive interpretation, like the realistic and referential notion of truth, is inevitably associated with a discredited and truncated ontology. Therefore, Heidegger deconstructed all ideas of an enduring nature or transcendental structure, revealing an epistemologically buried horizon of historicity encompassing all being and thought. Building on Heidegger's insights, Gadamer rejects both the form/content and understanding/application distinctions of traditional hermeneutical theory. Both differences assume the possibility of reconstructive interpretation, a strategy necessarily rooted in some foundationalist ontology. But such an interpretative approach fails woefully to understand the profound consequences of historicity. It is one reason why "tradition" is so central to Gadamer's thought. Having rejected foundationalist ontology, he must now uncover some other form of continuity that successfully avoids random pluralism and hermeneutical anarchy. ${ }^{27}$

\footnotetext{
${ }^{25}$ Cf. Joseph Dunne, Back to the Rough Ground: 'Phronesis' and 'Techne' in Modern Philosophy and in Aristotle (Notre Dame: University of Notre Dame, 1993), 108;

${ }^{26}$ So Gadamer says that "Romantic hermeneutics had taken homogeneous human nature as the unhistorical substratum of its theory of understanding and hence had freed the con-genial interpreter from all historical conditions." Truth and Method (New York: Continuum, 1993), 290. Gadamer, and now others in his wake, repeatedly use the label "Romantic" in order to identify certain $19^{\text {th }}$ century theories accenting psychological empathy with the author. But "Romantic" is a misleading term and unnecessarily limits the scope of the tradition that Gadamer seeks to overturn. This wider reality might better be named "reconstructive" or "objectivist." Cf. ibid., 385-406.

${ }^{27}$ Gadamer turns to the Hegelian ontologization of history and the "fusion of horizons" as ways of rescuing historical identity. The unity now established is quite different from any classical and inappropriate notion of material identity; it is instead a formal, historical continuity which allows Gadamer simultaneously to defend the importance of tradition and a vast plurality of textual readings. The triumph of Gadamerian hermeneutics in philosophical and theological circles has been so thorough and convincing that today hermeneutics is frequently spoken of as a replacement for metaphysics and epistemology. Cf. John. CAPuto, "Gadamer's Closet Essentia-
} 
What is attractive about Gadamer's hermeneutical theory? In the first place, he properly centralizes Heidegger's attempt to exhume the Lebenswelt from the obsequies pronounced by neo-Kantian transcendental philosophy. No naive positivism, bloodless transcendentalism, or abstract conceptualism could obstruct Heidegger's retrieval of the starkly tenebrous dimensions of historicity. Gadamer brought the full weight of Heidegger's ideas to interpretative theory, properly employing them to unmask hermeneutical positivism with its exaltation of subjective self-annihilation. ${ }^{28}$

To classical theological thought, however, postmodern hermeneutics presents a persistent and troubling challenge. Once the deconstruction of foundationalist ontology is accepted as demonstrated, certain conclusions inevitably follow. One such finding is the denial of the intelligibility of the form/ content distinction, the interpretative path undergirding the Magisterium's view of theological pluralism, inculturation, and bilateral ecumenical agreements. In all cases, it is claimed, there is an identity of content that may be reconstructed, transmitted from age to age, and then re-contextualized and re-expressed in a way that, while certainly allowing for new insights, formulas, and perspectives, also preserves the essential content of the original meaning. Postmodern thought, of course, regards such an approach as philosophically naive. The context/meaning distinction, with its corollaries of reconstruction and conservative re-expression, is only viable within the presumption of foundationalist ontology. But if such an ontology is unsustainable, what hermeneutical theory is now appropriate?

Traditional Christological dogmas are reflections on Jesus and the texts of the gospel. The Nicene and Chalcedonian definitions, however, represent Christ in a particular way, and thus they can still claim us. Nevertheless, the meaning of dogma is not irreversible, nor does it exclude other purposes, even contradictory ones. To say otherwise would mean to misunderstand the hermeneutical enterprise by ignoring the consequences of temporality, which have become entangled in the concepts of truth and interpretation. According to Bonsor, therefore, the dogmas of the early Church do not embrace reality itself. This position shows with absolute seriousness the consequences of radical historicity and the web of contingencies and beliefs in which human

lism: A Derridean Critique," in Dialogue and Deconstruction: The Gadamer-Derrida Encounter, edited by Diane P. Michelfelder \& Richard E. Palmer (Albany: State University of New York Press, 1989), 258-264

${ }^{28}$ Cf. Richard E. Palmer, Hermeneutics. Interpretation Theory in Schleiermacher, Dilthey, Heidegger, and Gadamer (Evanston, IL: Northwestern University Press, 1969), 129-133. 
life, thinking, and discourse are born. As such, it allows for a much greater plurality in terms of textual meanings and the truths arising from them. ${ }^{29}$

One may rightly harbor reservations about the theological hermeneutics of postmodernity. Does its rejection of the form/content distinction a problem in such broad pluralism that the unity and identity of the Church's evangelical and confessional structure are now unexplored? Does his tendency towards unlimited pluralism make it difficult, if not impossible, to ultimately defend the uniqueness of the saving mission of Jesus Christ? At the same time, postmodern thought applies an appropriate theoretical emphasis to any easy understanding of the context/meaning distinction. ${ }^{30}$

However, Karl Rahner has argued sophisticatedly and persuasively that both the Magisterium and theologians make the realization too easy by invoking this distinction, apart from the profound epistemological problems that accompany it. What are the form and content? How are they known? Is the distinction precise enough? Any subtle and sophisticated sense of interpretation knows how difficult these questions are. Indeed, one cannot speak of enduring content as a kind of ideal form, remaining beyond the profound and creative influences of theological authorship, social place, and various cultural domains that have a profound and productive impact on all thought. ${ }^{31}$

Nevertheless, the identification of rationality with scientific methodology and dissonance that appears between science, culture, morality, and religion are essential features of modern times. The above situation is, therefore, a significant challenge for modern Christianity and requires finding answers to the fundamental questions: how should a Christian respond to these problems? What should he/she do in this case? Can he/she hope for authentic and fruitful dialogue between the Church-understood as a depository of the message of Christ - and contemporary culture?

\footnotetext{
${ }^{29}$ Cf. Bonsor, Jack A. "History, Dogma, and Nature: Further Reflections on Postmodernism and Theology." Theological Studies 55, no. 2 (1994): 295-313.

${ }^{30}$ Cf. ibid., 304-310.

${ }^{31}$ Cf. Karl Rahner \& Edward Quinn, "Mysterium Ecclesiae," Cross Currents 23 (1973), no. 2: 183-198. True theological authorship, as well as genuine pluralism, inevitably lead to new perspectives and allow the organic, gradual, and natural development of the tradition. Therefore, reconstructive hermeneutics need not and should not lead to unimaginable immobilism. Properly understood, it sanctions a genuine surplus of a text and justified "undecidability" because new perspectives always allow (and even demand) that Christian symbols have features and dimensions that have not been seen before. Thus, objectivist hermeneutics should not be understood as an iterative repetition, even if it were possible (cf. ibid., 189-194).
} 
Undoubtedly, if the integrity and coherence of science, culture, morality, and religion-in the broad sense-are disturbed, there will no longer be possible any positive and helpful answer to the above questions.

Moreover, in a world based on calculations, it is the estimate of consequences that determines what should be considered moral and immoral (consequentialism). In this way, the idea of "moral good"-understood in terms of Christian personalism presented by Wyszyński-is replaced by teleological theories of moral obligation. They proclaim that the occurrence of a moral obligation depends entirely on the values of the actual or expected consequences of the acts that this obligation should cover. In other words, nothing in itself is clearly neither good nor bad. It all depends on the effects that can result from a specific human action. ${ }^{32}$

Therefore, if the statement that Christianity has acquired the most refined and unique cultural form in the Western world is right - it also seems fitting that the Western world has developed a culture that stands in the most radical contradiction not only to Christianity but to all religion and religious moral traditions of humanity. This fact, in turn, displays that Western culture is going through - in some way - a complicated and painful "surgical intervention" that requires equally complicated convalescence. The above analogy also draws attention to deep-rooted tensions, struggles, and conflicts of interest with which - in the context of culture - the modern world must face. $^{33}$

Hence, the Christian vision of commitment to culture is primarily associated with the responsibility that Christians who are obliged to take accountability for the culture, especially at this moment of history. In this sense, the debate about the profile and identity of modern civilization is not about waging another sentimental and pathos battle to defend Christianity. The matter seems much more severe. In this case, it is not just about the cultural future of Western civilization, but about all humanity. ${ }^{34}$

However, the attitude of the modern Western world to Christian culture is described in the best way by the discourse concerning the place of the

\footnotetext{
${ }^{32}$ Cf. Sam Harris, The Moral Landscape: How Science Can Determine Human Values (New York: Free Press, 2010), 29-43.

33 Cf. Stefan WyszyŃski, "Zło dobrem zwyciężaj. Do 'Solidarności’ z Gdyni. Warszawa, Kaplica Domu Prymasowskiego, 22 II 1981,” in Do „Solidarności“. Rady i wskazania (Warszawa: Soli Deo, 1996), 66-67.

${ }^{34}$ Stefan WysZYŃSKI, "Moc żywej wiary w ciężkiej sytuacji Kościoła. Do duchowieństwa w Gdańsku, 23.11.1960,” in Stefan WYSZYŃSKI, Nauczanie społeczne 1946-1981 (Warszawa: Ośrodek Dokumentacji i Studiów Społecznych, 1999), 166
} 
Church in public space. Admittedly, her institutional rights are guaranteed but only based on generally accepted political compromises. Nevertheless, every effort is being made to ensure that the Gospel message preached by the Church does not have a real impact on the fundamental spheres on which Western civilization is based (law, culture, media world, etc.) ${ }^{35}$

The main motives for discrediting the Christian vision of socio-cultural life evoke the idea that only a radical culture born on the basis of the concepts of the Enlightenment era-which has now reached its full development - can and should constitute the civilizational identity of the Western world. In this context, various other religious cultures-including Christianity, along with its Gospel principles - can coexist side by side under condition (and to such extent) that they would respect the criteria of the Enlightenment culture and obey its precepts.

\section{TOWARDS NEW CHALLENGES}

The fundamental paradigm, on which the culture of Enlightenment is based, is the idea of freedom described as the primary identifier and criterion for all other values: freedom of choice regarding religion, which also includes religious neutrality of the state; freedom of expression (provided that it does not accurately challenge any question of political correctness); democratic order of the country, i.e., parliamentary control of state organs; freedom to form political parties; independence of persons involved in the functioning of the judicial system; and finally, protection of human rights and non-discrimination. ${ }^{36}$ In this context, the scope of the concept of discrimination is continuously expanded. And this means that the prohibition of discrimination may lead to restrictions on freedom of expression as well as religious freedom. ${ }^{37}$

${ }^{35}$ Cf. Thomas E. Woods, How the Catholic Church Built Western Civilization (Washington, DC: Regnery, 2005).

${ }^{36}$ In this case, the canon of important issues is still in statu fieri, because there are contradictions in the very system of human rights, which we see - for example - in the conflict between the right of a woman to freedom, and the right of the unborn child to live. Cf. David Platt, Counter Culture, Following Christ in an Anti-Christian Age (New York: Tyndale House Publishers, Inc, 2017), 59-80.

${ }^{37}$ Referring to supporters of liberal concepts, Wyszyński pointed out: "Some people proclaim a man as a god himself. They multiply his laws at the expense of God himself and weaker fellow men at the cost of society and the state. Everything is to worship man. There are no restrictions here. They submit everything to the highest and irrevocable judgment of a man: they proclaim his 
Even today, it is challenging to talk critically about the problem of homosexuality, LGBT ideology, or the issue of ordaining women, which is against the official teaching of the Church. Nevertheless, the canon of ideas and values approved by contemporary culture also includes those that are of great importance for Christianity as well. However, given the fundamental issue of freedom, for example, the problem is that the above value is very often wrongly understood and interpreted. Therefore, it inevitably leads to many overinterpretations and even contradictions. Consequently, putting this concept into practice results in restrictions of freedom that we could not even imagine in the past. Moreover, the confused ideology of pseudo-freedom leads to uncritical dogmatism, which turns out to be increasingly hostile to a personalistic vision of freedom rooted in the Christian concept of the human person. ${ }^{38}$

Moreover, the secularization of contemporary culture emphasizes that only such norms and content can determine the identity of today's Western world. In this sense, any country that accepts these criteria (whether it's Turkey or Israel, or any other most exotic states) can belong to this-socalled-world. As a result, an attempt is made to argue that historical and cultural identity is not very important. On the contrary, more important is the "new identity" based on Enlightenment standards. Nevertheless, here, nei-

moral freedom, freedom from all social obligations. They recognize only private morality for personal use. Man can do whatever he likes - morality is his only private thing. They do the same with God. Religion is also a private matter of man. Perfection and the pursuit of God have no social significance. Man's supreme happiness is his ultimate goal. This goal can be pursued by all means, because here there are no moral rules. Economics and ethics - these are foreign fields. There are no higher laws, God's commandments, which should be subjected to human social and economic life. Freedom to get rich - this is the highest economic law. Everything should serve a man for protection in his pursuit of personal well-being; even religion and the state should protect their temporal interests. Man is homo oeconomicus. Nothing more! Everything else is a small addition to life and should serve one purpose. A neighbor is a 'human material,' placed on a par with raw material in some production costs; fellow-men - this is the amount of work, the weekly pay, the physical strength, the officer. And nothing more! Nothing else binds us to him." WYSZYŃSKi, Miłość i sprawiedliwość, 46.

38 "The fact that the communist states based the economy on the capitalist system of work is simply the result of a derivative relationship between collectivism and capitalism. It is their original sin. Both systems originate from the same materialistic philosophy. Both practically proclaim the supremacy of things over a person, and both do not successfully defend a man against the demon of technocratic. Moreover, it gave the man to the service of the economy against the rights of the human person." Stefan WYSZYŃSKI, "Problem pracy górników w Polsce. List do księdza biskupa Herberta Bednorza, 2.02.1978," in WysZyŃSKI, Nauczanie spoteczne 1946-1981, 810-811. 
ther God nor the Christian cultural heritage has too much to do with the socio-political reality of the modern West.

In this context, many representatives of contemporary postmodernism unequivocally question the need for ethical codes, describing them as an ethical heteronomy that violates the human right to moral choices. However, their position is not the same as rejecting the need for morality as such in human life. Nevertheless, they believe that morality is only possible down to the dimension of personal belief - an individual "ethical" view. Though, the question arises: what is the source and nature of moral experiences and decisions?

One of the most prominent representatives of postmodernism, Zygmunt Bauman, in his deliberations on morality, combines quite different themes: ethical emotivism, Kantism, and Lévinas' phenomenology. ${ }^{39}$ While Kant spoke of the "categorical imperative," Bauman uses a slightly different language and mentions the "moral sensitivity" or "moral skill" of man. ${ }^{40} \mathrm{How}$ ever, they both share the conviction that a person has the internal ability and need to make moral decisions. Though, while Kant treated moral imperatives as acts of human will, Bauman favors emotivism. He characterizes "moral phenomena" as irrational, aporeutical (which is supposed to result from the ambiguity of human situations), and irrational. ${ }^{41}$

Nevertheless, postmodernity is an attitude of distrust towards reason, the consequence of which is the appreciation of the emotional sphere of a human person. Thus, morality cannot be a product of human rationality but is an internal-emotional experience. "The moral self has no foundation," but it rests on the "moral impulse." As a result, morality explained in the context of emotivism has a clearly irrational profile. Bauman's position on ethical issues is, therefore, exact: he proposes morality without ethics. It would be a morality established by an individual as an autonomous subject, thus giving up permanent universal ethical norms. The moral act begins in solitude, so it has an individual and personal character. Therefore, there is no common good upon which to construct a code of ethics. ${ }^{42}$

This is undoubtedly extreme individualism in explaining the phenomenon of morality. The proposition of morality without ethics advocated by Zyg-

\footnotetext{
${ }^{39}$ Referring to Immanuel Kant, Bauman states: "It is the elementary and primal 'naked fact' of moral impulse and moral responsibility that provides the material from which human coexistence is made." Zygmunt Bauman, Etyka ponowoczesna, trans. Janina Bauman \& Joanna Tokarska-Bakir (Warszawa: Wydawnictwo Naukowe PWN, 1996), 49.

${ }^{40}$ Cf. ibid, 49-50.

${ }^{41}$ Cf. Stanisław KowalczyK, "Etyka postmodernizmu." Idō - Ruch dla Kultury 4 (2004): 334.

${ }^{42}$ Cf. Bauman, Etyka ponowoczesna, 87-89.
} 
munt Bauman, despite noble intentions, is questionable for many reasons. Of course, it should be appreciated that - as a supporter of postmodernityBauman recognizes the need for morality in the human's personal and social life. His disapproval of eugenics as a form of social engineering, as well as his firm condemnation of all forms of genocide and ethnic persecution, also deserves recognition. ${ }^{43}$

The negation of normative ethics is, however, a joint position of all representatives of postmodernism. In this context, however, a general doubt arises: is genuine morality possible without any principles? Ethical emotionism and situationism is deeply rooted in relativism (in fact, it is an integral part of relativism). If there are no general moral norms (normative ethics), then it is impossible to rationally justify the condemnation of any criminals' acts, which - if we accept Bauman's proposals—should also be granted the right to moral autonomy.

This idea seems to be in fundamental contradiction to the views of Cardinal Wyszyński, who stated: "The Gospel establishes a real parity of humanity by measuring the value of man with the intentions of the Creator." Thus, everything that makes up the reality of the human person, including culture, is a gift of God. Hence, through the will of the Creator and by this priority, the entire material order is subordinated to the human being, both temporarily and eternally. ${ }^{45}$

In other words, the personalistic vision of the human person revealing the greatness of man, at the same time, emphasizes his infinite dignity as a person. "Human desires and aspirations come together with the properties of the Creator. So there is in us the Heavenly Father's heritage that Christ makes us aware of. Therefore, we can say that we carry within us the qualities of the

\footnotetext{
${ }^{43}$ However, the main concern is that "moral impulse" (conscience?) is an inalienable attribute of man is questionable, but it does not justify any universal moral principles. What, then, is this impulse: a purely personal emotional experience? Isolating the conscience from the rationalvolitional sphere of a person comes down to fleeting irrational feelings, based on which it is difficult to speak of genuine responsibility for one's own life and the life of other people. Bauman's concept of morality, a representative of postmodernism, quite clearly refers to the theory of emotivism, recognizing the emotional sphere as crucial in the genesis of moral experience. Cf. Zygmunt BAUMAn, Wieloznaczność nowoczesna i nowoczesność wieloznaczna, trans. Janina Bauman, revised by Zygmunt Bauman (Warszawa: Wydawnictwo Naukowe PWN, 1995), 70-78.

${ }^{44}$ Stefan WyszyŃski, "O pokoju na ziemi: Po ogłoszeniu encykliki «Pacem in terris». Białystok 2. 06.1963," in WYSZYŃSKI, Nauczanie społeczne 1946-1981, 679.

${ }^{45}$ Cf. Seweryn Rosik, "Promocja aksjologicznej pozycji osoby ludzkiej i wspólnoty rodzinnej niektórych dziełach Kardynała Stefana Wyszyńskiego," Roczniki Teologiczne 38-39 (1991-1992), issue 3: 85 .
} 
Creator, our Father, and His aspirations are implanted in us-in the great and powerful Womb of Heavenly Father, from which we all stem from. From Him, we inherit all desires, aspirations, and hunger, which are also our life desires" ${ }^{46}$.

In other words, both religion and morality need God. As mentioned earlier, modern reflection, especially in the empirical sciences, is getting more and more distant from the question of God, but it needs morality. In this case, one can notice a real split, which Kant could not overcome, becausetaking into account the methodology adopted by him-his logic of separation and distinction was more robust than the sense of unification and harmonization. According to personalism, human reason ceases to be genuinely compassionate and takes on the attributes of "divinity." Therefore, a realistic ethical concept-first and foremost-should take into account the relationship between the human subject of morality and the universal moral law. ${ }^{47}$

As Wyszyński put it: "A man does not need records that fall within the scope of the fundamental rights of a human person, because these rights cannot be questioned, the man simply owns them. If these rights were denied, as a result of some political system, then a severe alienation and contortion of both the system and the entire social and political life would be created." 48

Consistent with the assumptions of personalism, the ethical system should be developed based on an analysis of human moral experience while examining its metaphysical roots. In this sense, morality itself is undoubtedly inscribed in the ontic structure of man as a person. For personalism, this kind of reflection is possible and justified. Nevertheless, man is not only a being who makes mistakes and errs (errare humanum est) but, above all, he is a being naturally open to fundamental and universal truths (homo capax veri).

The rationality of the Enlightenment era has produced remarkable and valuable fruits. Without this, one cannot imagine dizzying scientific progress, outstanding achievements in the field of culture, technology, and eco-

\footnotetext{
${ }^{46}$ Stefan WYSZYŃSKI, “«Homo Dei». I kazanie świętokrzyskie 13 I 1974,” in WysZYŃSKI. Nauczanie spoleczne 1946-1981, 576.

${ }^{47}$ Cf. James Luchte, Kant's Critique of Pure Reason: A Reader's Guide (London, New York: Continuum, 2007), 56-61

${ }^{48}$ WyszyŃSKI, Stefan. "Do «Solidarności» wiejskiej rolników indywidualnych. WarszawaMiodowa 2.02.1981," in WyszyŃski, Do „,Solidarności”. Rady i wskazania, 79.
} 
nomics, civil as well as constitutional rights, which irreversibly changed the face of the Western world. The above achievements also conditioned the civilization changes: the scientific revolution was followed by a technological revolution as well as an industrial revolution, followed by revolts in politics, social life, and individual rights.

Moreover, thanks to the above idea of rationality, Europe has developed a culture that, especially now - in a manner previously unknown to humanity - is trying to exclude God from the sphere of public consciousness. Indeed, the existence of God can be denied entirely or considered impossible to prove, assuming that faith or disbelief is a matter of subjective choice. Nevertheless, in both cases - in the opinion of many modern ideologists God should not matter to public life. However, this type of reasoning is rooted in extremely anti-religious scientism, which maintains that only empirical sciences - free from experimentally unverifiable theories that do not have the ambition to explain everything based on one, a priori philosophical principle - can obtain "accurate" knowledge of reality. So, only these issues can be sensibly resolved or can be explained in the language of such experimental sciences. All other problems are undecidable (due to the appropriate scientific method limitations) or completely nonsense because of language ambiguities. In this context, the idea of scientism as a conceptual attitude is expressed in the slogan: "science instead of religion."

Such ideas contradict the concept of culture presented by Wyszyński. According to him, only a personalistic vision of Christian culture enables people to realize the personal fullness of man both temporarily and supernaturally. That is why Wyszyński puts the human person at the center of his concept. In this context, man becomes its principal subject, goal, and sense of the entire cultural order. In other words, the human person cannot live and function in isolation from culture, but neither can one speak of an authentic culture isolated from the background of the whole truth about the man and the world in which he/she lives.

Personalistically understood culture thus becomes a special gift through which a person can realize himself also in the social dimension. Therefore, it is a fundamental task to create an authentic humanist culture space through

\footnotetext{
${ }^{49}$ However, Christian morality belongs to a completely different order than the already mentioned concept of rationality, which - according to proponents of this way of thinking - loses its relevance as concrete and necessary category. Moreover, since society nonetheless needs "some" morality - according to many contemporary coryphaeuses of postmodernism - it must be rediscovered, based on a new "scientific" paradigm. Cf. Moti Mizrahi, "What's So Bad about Scientism?" Social Epistemology 31 (2017), no. 4: 351-367.
} 
its commitment, capable of shaping a human person according to his calling. It is possible, however, thanks to the sphere of personal values that condition the transformation of the whole reality of the world. From the theological point of view, it is expressed primarily through the cooperation with the God-Creator in the work of perfecting His design. Complementing the perspective of Creation with the mystery of the Incarnation and Redemption accomplished by Jesus Christ is the crowning of the historic-salvific relationship of man with God. Therefore, culture inscribed in the perspective of Creation represents an essential dimension of the relationship of a human person to God. It also emphasizes the unique dignity of man and his vocation understood as the full realization of the person in the individual and social aspect-and thus the humanization of the entire earthly cultural reality in the spirit of Christ's Gospel.

Nevertheless, the question remains: is the progress of civilization universal? To a large extent, yes. Undoubtedly, the changes taking place in the complex temporal reality are global and bring significant benefits. Furthermore, inscribed in the powerful dynamics, vitality, operability, and enthusiasm are associated with their general acceptance. In turn, the ability to further develop requires that they remain socially attractive.

However, does the above progress meet all the expectations of a (post) modern man? Is this maybe the "Pyrrhic victory" of Western civilization? Undoubtedly, a side effect of these changes is marginalization, alienation, and objectification of a large part of Western society. Additionally, it is the triumph of extreme individualism, libertinism, and expressly understood human subjectivity, which leads to total enslavement, and-above allaversion to what is "divine," sacred, and supernatural. This kind of tendency has already led to put God into a "kind of ghetto." In turn, it leads to general confusion in the sphere of values and social deadlock. In the context of culture, the above process manifests itself in deepening apathy, soullessness, and even destructive decadence (anarchy and the cult of "anti-values." 50

\footnotetext{
${ }^{50}$ The Christian vision of culture does not allow reducing this field only to a set of strictly emancipated system, which can be analyzed only on a temporal level, without reference to the axiological dimension. Of course, Catholic social teaching approves the reality of culture inscribed in the realities of the market economy and competition as essential tools shaping modern social life. However, it does not mean the acceptance of such a cultural model, where hedonism and consumerism are put above the good of the human person, and the individual interests of individuals dominate the "common good" of the entire community, while at the same time compromising the principle of solidarity. That is why the Magisterium of the Church emphasizes in her teaching the necessity to enter involvement in socio-cultural, economic, and political
} 
Paradoxically, the Western world has developed a culture that - in a measure unknown so far in human history-excludes God from socio-cultural consciousness.

Unfortunately, the above problems even affect a vast number of practicing Christians who do not always treat their faith as a fundamental paradigm for their lives and actions. It is also reflected in the dimension of culture, art, science, and education ${ }^{51}$. Little wonder, therefore, that modern man is increasingly experiencing ideological emptiness, and the cut-off from Christian roots leads to a growing loss of identity and deepening alienation. Not surprisingly that societies experienced the Marxist materialistic ideology, as well as modern cultural neo-Marxism-despite the persistent propaganda emphasizing its cultural dominance-are experiencing increasing uncertainty, a sense of weakness, inertia, and fear. As Wyszyński states: "One cannot deny the fundamental Christian thesis: although a man in his actions and efforts to take over the land is limited, (...) he should nevertheless remember that he has primacy before the created world." 52

The ubiquitous cultural crisis affecting Western civilization is also associated with the consequences of the "rationality" of the Enlightenment eraor, more precisely, the concept of rationality, which trusts only narrowly understood science (scientism). Meanwhile, it is hostile towards the moral teaching of the Church. An excellent example of this is the modern discourse on bioethics. In this context, the ambivalent gains of the scientific revolution are clearly visible, emphasizing the need to separate the various spheres of

activities in a broader moral context. Therefore, it cannot be accepted that the economy should be transformed into a kind of political system serving exclusively secularized liberal ideology. Cf. Michał Gierycz, "Przejawy instrumentalizacji religii w polskiej polityce," in Ile Kościoła w polityce, ile polityki w Kościele, ed. Piotr Burgoński, Józef Kupny, \& Sławomir Sowiński (Katowice: Księgarnia św. Jacka, 2009), 179-203.

${ }^{51}$ Indeed, the era of enlightenment has undoubtedly Christian roots, which is often forgotten. Nevertheless, modern rationality — which is the fruit of that era - turns out to be more and more barren. Moreover, despite the growing process of ideological "entrapment," post-Enlightenment rationality has created a specific autogenic myth: 'faith' in its own potential and absolute 'selfsufficiency' - a kind of autarky of the non-religious sphere, which is attributed almost supernatural attributes. As a consequence, the above mechanism generates more and more radical secularization and laicization, which - in the past - quite positively stimulated human development and the progress of entire societies. Currently, however, in their radicalism and fierceness, the above trends have turned against their creators and promoters, carrying serious civilization threats. Cf. "List Episkopatu Polski do duchowieństwa o moralnym zagrożeniu narodu. Warszawa 25 I 1968," in Listy Pasterskie Episkopatu Polski 1945-1974 (Paris: Editions du Dialogue, 1975), 508.

${ }^{52}$ Cf. Stefan WyszyŃsKi, "Nasze dezyderaty. Do profesorów katolickiej nauki społecznej, Jasna Góra 22 I 1963,” in Stefan WYszYŃSKI. Nauczanie spoleczne 1946-1981, 197. 
competence for scientific research (also in the context of culture philosophy) in the name of the autonomy of earthly reality. In this case, it reveals how fragile and shaky the balance between science and technology as well as morality and religion is.

The classical understanding of man as a member of a given community

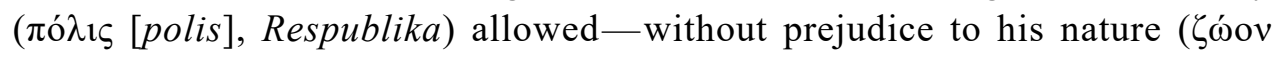
$\pi \mathrm{o} \iota \tau$ ıкóv [zōon politikon]) — to link his physical and spiritual development with the growth of a given secular society, and also a religious as well as a church community. However, when man began to be understood in an individualistic-nominalist way, all subordination to society began to be treated as a threat to his freedom. In this case, personalism defends the autonomy of man as a person who, existing within a given community, grows "above it," both by thought, will, and by his activity.

In this context, as the Cardinal emphasizes: "The fundamental mistake is to renew a family, nation, state, or system without renewing a man. One must first recognize that man has the right to his Savior-Renewal, in every dimension. This law is significant and irreversible that any attempt to separate man from Christ is suicide for the family, nation, and the entire political system." 53

Also, the right to express oneself-inscribed in a broader range of human rights to respect your dignity - has Christian roots anchored in the "creative" and "saving" context of the Good News' message. In this sense, the Enlightenment aspirations to transfer the Christian idea of respecting the human person and promoting his personal dignity to secular law meant

\footnotetext{
${ }^{53}$ Stefan WyszyŃski, "Przemówienie w Boże Narodzenie w archikatedrze św. Jana Chrzciciela. Warszawa, 25 XII 1978," in Prymas Tysiaclecia, ed. Florian Kniotek (Paryż: Editions du Dialogue, 1982), 274. Presenting the human person as the first and fundamental value of the social order is, however, connected with the necessity to recognize the whole system of rights and obligations which, rooted in the nature of man, condition his life and actions. Man - as a being characterized by his potentiality — has an "inherent" need for openness to the "outside" world. Therefore, a human being - by using his personal abilities and engaging in social life-can realize his Christian calling, both in a natural and supernatural dimension. The above principles do not have much in common with the specifically understood standards rooted in the "rationality" of the Enlightenment era, which is now considered - practically the only — "sacred" and inviolable. However, the human being has a right to express himself freely, without any restrictions or restrictions from the outside, at least as long as the freedom of the individual does not violate the rights of other people. Moreover, as a guiding idea, the above law has become a filter through which one tries to purify and authenticate every additional value. Cf. Ryszard FiceK, Christians in Socio-Political Life: An Applied Analysis of the Theological Anthropology of Cardinal Stefan Wyszyński, Primate of Poland (Toruń: Wydawnictwo Adam Marszałek, 2020), $69-84$.
} 
significant civilization progress. Nevertheless, when other achievements joined it (among others, unlimited freedom of scientific research, the autonomy of culture and technology, issues of gender ideology, or the issue of women's self-determination, including the controversial problem of abortion and euthanasia), the situation turns out to be much more complicated.

In this sense, the anti-population policy of the state has made negative changes in social mentality. "Society was infected with an unprecedented fear of reproduction. Multi-children families were considered almost antisocial. The spouses began to renounce more offspring not only because of difficult living conditions but more often for fear of condemning public opinion." ${ }^{54}$

Challenging all authorities and undermining fundamental moral principles entails a severe threat of demoralization of society, in particular the young generation. Realization of such attitudes as agreeableness towards evil, ridicule of value, egoism and comfort, consumerist attitude towards life, sexuality, drunkenness, and drug addiction becomes a real manifestation of this problem. ${ }^{55}$ Therefore, it causes a widespread moral crisis, which is associated with a weakening of faith, contributes to the degeneration of the system of fundamental moral values, and thus directly harms the biological and cultural foundations of social life.

\footnotetext{
${ }^{54}$ Stefan WyszyŃski, "W obronie religii Chrystusowej i bezpieczeństwa ojczyzny. Podczas uroczystości Królowej Polski na Jasnej Górze 3.05.1973," in WYSZYŃSKI. Nauczanie społeczne 1946-1981, 548. In common crimes of infanticide committed in Poland "in the majesty of the law," Primate saw the causes of biological and moral degradation threatening the Polish nation. For this reason, he consistently demanded the introduction of a total ban on the murder of unborn children who have the same right to life and development as those who are born. Therefore, they should enjoy absolute legal protection from the moment of their conception. Cf. "Memorial Episkopatu polski do rządu PRL w sprawie zagrożeń biologicznych i moralnych Narodu Polskiego. (1970)," in Prymas Polski w obronie życia nienarodzonych, cz. II (Warszawa: Ośrodek Dokumentacji i Studiów Społecznych, 1982), 306.

${ }^{54}$ In a memorial addressed to the government of the Polish People's Republic in 1970, together with the entire Episcopate, he sharply stigmatized existing legislation and practices in the field of protecting unborn children. Referring to international law, he mentioned the "Declaration of the Rights of the Child" adopted unanimously on November 20, 1959, by the UN General Assembly and to the 'International Covenant on Civil and Political Rights' adopted by the UN General Assembly on December 16, 1966, which clearly state that every human being has the inherent right to life. This right should be protected by law, and no one may be arbitrarily deprived of life. Cf. "Memoriał Episkopatu polski do rządu PRL."

${ }^{55}$ Cf. Stefan WyszyŃski, "To jest nasz program prymasowski. Do wiernych w bazylice prymasowskiej w Gnieźnie 2 II 1957," in WYSZYŃSKI, Nauczanie społeczne 1946-1981, 75-76; WYsZYŃSKI, "Nasze dezyderaty," 198-200; “O zagrożeniu moralności narodu. List pasterski na Wielki Post 1968," in WYSZYŃSKI, Nauczanie społeczne 1946-1981, 343-348.
} 
Nevertheless, the most difficult and most controversial problems that contemporary civilization faces today are bioethical issues. In particular, the justification why-following applicable law on particularly abortion and artificial insemination, but also euthanasia - the right of the unborn person or infirmed to live must give way to the right to freedom, self-determination, and self-realization of other individuals. ${ }^{56}$

It is here that the absurdity of the Enlightenment thesis emphasizing the need to separate the scientific, legal, moral, and religious sphere, which guarantees the elimination of conflicts and the balance of the entire social life system in all its dimensions, can be seen. In fact, it is quite contrary. Practically, always mindless and irresponsible interference in any of these spheres-even in the name of an expressly understood right to realize human freedom-leads to negative consequences that have been felt by all social structures. In other words, depriving the scientific and cultural sphere of the supernatural dimension will remove religion from human life. Separating morality from the legal system will contribute to the deprivation of all values in the legal and judicial system. Also, in a situation where science and technology gain unrestricted freedom to achieve their goals, without taking into account ethical factors, civilization's progress may turn out to be blind or even destructive. ${ }^{57}$

\footnotetext{
${ }^{56}$ The reason for abortion is still not clear. It is because the unborn person is not a person. Therefore he/she does not have the right to life of a human person? Maybe because they are "small" and unable to defend themselves, and the lives of the youngest can be sacrificed for the "good" of adults? Maybe because abortion is considered - a sort of - a "little murder," which in practice is not a real murder? Or maybe because the unborn person does not belong to those "others" who define the absolute limit of the "human" right to individual freedom? In the opinion of Cardinal Wyszyński, the normative basis for human rights, their source, and the most profound justification are norms in their existence and their content independent of the establishment of legislative power. Cf. Stefan WYSZYŃSKI, "Prawa osoby ludzkiej w społeczeństwie. Warszawakościół św. Anny 18. 03. 1957,” in Stefan WYSZYŃSKI, Kazania i przemówienia autoryzowane 1956-1981, vol. 1-67 (Warszawa: Archiwum Instytutu Prymasowskiego w Warszawie, 19561981), vol. II, 4-5. Cf. Henryk Sкоrowsкi, Problematyka praw człowieka: Stadium z nauki spotecznej Kościoła (Warszawa: Akademia Teologii Katolickiej, 1996), 21; Joanna KowalsKA, “Kardynał Wyszyński w walce o człowieka sumienia," Społeczeństwo 26 (2016), no. 3: 131-136.

57 Stefan Wyszyński, "Dobrzy bracia. Podczas uroczystości 250 rocznicy bonifratrów do Warszawy 26 IX 1976,” in WYSZYŃSKI, Nauczanie społeczne 1946-1981, 748.
} 


\section{THE CRISIS OF CHRISTIAN CULTURAL IDENTITY IN THE CONTEXT OF CONTEMPORARY POST-ENLIGHTENMENT TRADITION}

An emphatic example of the Christian culture's crisis is the possibility of the emergence and functioning of totalitarian systems of the $20^{\text {th }}$ century, responsible for terrible crimes against humanity.

Reporting on the Nazi-human concept of man, Wyszyński states with some sarcasm: "The greatest disgrace to man would be any relationship with God, especially in the Christian sense. Man, God's creation? This wording is enough to draw all the hatred that is exercised towards God. There is widespread contempt for the image of God in man, even easier to perpetuate because people do everything in order not to remember God in anything. A man stripped of the remnants of a relationship with God is considered directly as a fertilizer for future generations."

Therefore, the culture and vision of human life presented by ideologists of the Third Reich, especially to the community - in their opinion"racially inferior" is terrifying. "Man lives purely animal life. He feeds himself to live and have the strength to work-work for the masses, waste his strength, and when a man becomes less and less useful, he should go away, not to stand in the way of the young. His highest value is race and pureblood, which he should pass to the coming generations. The entire value of a man is confirmed by belonging to a chosen race. If there is no specific blood group in it, he is not a human being; he has no right to life. He is a parasite! It is a merit to remove the parasite so that the people could live and develop without hindrance." 59

In turn, analyzing the collectivist culture and ideology of Marxist-Leninist supporters, Wyszyński emphasized: "Man does not have any personal value in their eyes. Not only is it not the center of the world, but it is also merely nothing. It takes its entire value from giving to the state through social co-existence. Therefore, firstly, people are denied the rights of a person: freedom, thinking, and acting. Man is subject to unconditional obedience to the supreme power: people must be listened to rather than God." 60 "The human person is subjected to complete contempt, the inexorable hardness of the system of government, the inhumanity of great lawlessness, despotism,

\footnotetext{
${ }^{58}$ WYSZYŃSKI, Miłość i sprawiedliwość, 47.

${ }^{59}$ Ibid.

${ }^{60}$ Ibid, 46-47.
} 
and terror. In practice, citizens are enslaved to the community. Secondly, people are denied the freedom to believe in and worship God. For in man, the eternal principle is not recognized, nor any other destiny other than temporal. Hence the organized, official struggle against religion-as a new task of the current state. Hatred organized!" 61

"Communism wants to build a world without God. Man wants to be brought up without the commandments of God and religious morality, only based on the morality of the mass. (...) Man is the new god of a man - the highest happiness: proletarian equality. Therefore, man, created in the image and likeness of God, detached from his Creator, is thrown into the depths of godlessness and mortality. Thirdly, one's destiny and individual goals are rejected. He has no soul and no destiny." 62

"Moreover, no one can measure man's goal of pursuing happiness in God. Man is obliged to pursue these goals, which the state will show him. He must be socialized, all over his body and soul. He must sacrifice all, fulfill all community orders. Finally, fourthly, a new goal is imposed on man, indicated by collective life. Because spiritual values have no meaning, hence the goal of the highest human life will be the good of the state, society, Nation, class, party or economic good, organized atheistically, temporal, material happiness, earthly or capitalist paradise: through self-profit or also through communist profit. In other words, the deification of matter, profit, production, technology." "B3 "Beyond the human being, there is no personality, no rationality, and no freedom." ${ }^{64}$

In this context, another problem arises: can modern philosophical concepts inspired by the ideas of Enlightenment be considered the quintessence of the Christian cultural strategy proper to modern man?

In general, the above statements are characterized by a positivist-and thus anti-metaphysical - attitude. Therefore, there is not much room in them for God. In their assumptions, they are based on the methodology of "selflimitation" of positivist reasoning, which—to no small extent-is sensible

\footnotetext{
${ }^{61}$ Ibid.

${ }^{62}$ Ibid.

${ }^{63}$ Ibid., $47-48$

64 "Społeczność przyrodzona i nadprzyrodzona. II Konferencja Akademicka. Warszawa - kościół św. Anny 16.02.1957," in Kazania i przemówienia autoryzowane 1956-1981, vol. 1-67 (Archiwum Instytutu Prymasowskiego w Warszawie), vol. II: 61.
} 
in the technological dimension. Nevertheless, it is connected with severe problems, taking into account the Christian concept of man, especially in the personalistic sense. In this sense, man no longer accepts any moral authority other than his own calculations and interpretations. Thus, even the concept of "liberated freedom," which initially seemed capable of exceeding the limits of temporality, consequently leads to the denial of its limitlessness, and - eventually - to the negation of the freedom at all.

Positivist philosophical systems also emphasize the idea of truth. However, for similar reasons, especially in the cultural dimension, it is difficult to speak of "objective" truth, taking into consideration their strong roots in the principles of moral relativism. Thus, although current system assumptions influencing the vision of culture seem to be rational, in reality, they are often not even the voice of common sense. Therefore, it should be stated that the philosophy of Enlightenment, along with its parallel culture, display serious deficiencies. They rely primarily on deliberate separation from their historical roots. In other words, one can see a radical departure from what can be defined as the "basic memory of humanity" also interpreted as "tradition" (in this case understood as a "Christian ethos"), conditioning the cultural identity of contemporary Western culture without which reason loses its orientation.

Like Marxist ideology in the past, also neo-Marxism today promotes many destructive activities that pose a severe threat to modern public life. Moreover, they are stimulated by a programmed process of inciting and fueling selfishness as well as social hatred (consumerism, hedonism, moral permissiveness, or exacerbation of racial conflicts, social divisions due to sexual orientation, cultural and political preferences, etc.). In this case, culture is an excellent tool to promote this kind of ideology. ${ }^{65}$

"It is significant—as Wyszyński pointed out—that in the aspirations for the proletariat's liberation, a lot of room is occupied by religious and moral matters, or rather the fight against the Christian religious worldview ${ }^{66}$. As erroneous doctrinal assumptions, hatred is recognized as a motor force of progress, applying the principle of divide et impera. The Christian spirit of forgiveness and peace is declared war in the name of alleged justice, and primarily in the name of pagan hatred." ${ }^{67}$

\footnotetext{
${ }^{65}$ Cf. FiceK, Christians in Socio-Political Life, 46-47.

${ }^{66}$ Cf. Wyszyński, Miłość i sprawiedliwość społeczna, 103.

${ }^{67}$ Cf. "List Episkopatu Polski do duchowieństwa o moralnym zagrożeniu narodu," 507.
} 
The spread of the attitude of egoism and social hatred appears as a severe distortion of spiritual and moral culture, which harms both the dignity of the human person and the unity of the Nation. Therefore, programmatic hatred, destruction of love understood as the basis of agreement, became a dangerous threat to both the human person and family as well as to the nation, which, broken and internally divided, is deprived of future prospects. "The illusion that raises many misfortunes for peoples and nations is the belief that one can build on unbelief, atheism, and class struggle, while-in reality - our world can be created only through brotherly mutual love. If today's world needs something, it is faith that we come from God who is Love and does everything in love: from God who first loved each of us." 68

However, the problems mentioned above cannot be solved by returning to a kind of one integrated form of "knowledge" rooted in "Christian wisdom and prudence," which would harmoniously cover all areas and allow solving the fundamental problems of humanity. After all, original sin also left its effects over here. Using the biblical paraphrase, therefore, the consumption of the forbidden fruit from the tree of the good and evil's knowledge caused that the paradise reality was lost once and for all. ${ }^{69}$

After all, however, it is possible and even necessary to recall ethical boundaries that science and technology cannot cross. Similarly, the requirement that the sphere of values permeates the entire legal system is indisputable. Undoubtedly, we pay a high price for the dynamics of civilization changes and the gap between the speed with which science and technology offer us tools to satisfy our desires and the pace at which humanity manages to understand the functioning of these instruments, taking into account side effects that are difficult to predict. Most important, however, is the balance and compatibility between wisdom and knowledge, and above all, between the Enlightenment's rationality and the prospect of salvation to which Christians are called.

It is demanded by the Wyszyński's personalistic concept of culture. According to him, the human being was finally formed in all his being by God, the Creator, who made a mark of His greatness in man's nature. This greatness does not come from human giving, but it is established by the creative act of God's love. That is why every human person is related to others in God Himself. ${ }^{70}$

\footnotetext{
${ }^{68}$ WYSZYŃSKI, "Dobrzy bracia," 748.

${ }^{69}$ Cf. Stefan WyszYŃSKi, "Zwycięstwo wiary naszej. Do duchowieństwa Warszawy 24 XII 1973," in WYSZYŃSKI. Nauczanie społeczne 1946-1981, 570.

${ }^{70}$ Cf. Stefan WYSZYŃSKI, "O katolickiej woli życia. List pasterski na Wielkanoc 1947," in WysZYŃSKI, Nauczanie społeczne 1946-1981, 34-36; IDEM, WYSZYŃSKI, Stefan. "Wołanie ludz-
} 
The above thesis is in apparent contradiction to collectivism, on the one hand, and egocentric individualism, on the other. Socialism reduces the understanding of the genesis and nature of man to relations and social forces, instrumentalizing and losing human subjectivity, to creating the conditions of a totalitarian model of social and political life. Individualism, especially in its extreme forms, sees only the "external-biological" relationship of man with society in terms of individual species. Personalism emphasizes that man, having a substantive self-identity, by his nature, needs a second human being in the sense of the human phenomenon, which is love. ${ }^{71}$

In other words, the specificity of the Christian life is expressed primarily in the fundamental moral obligations. Only in this context can we speak of individual attitudes or moral norms - including Christian commitment to socio-economic and political life inscribed in the dimension of culture-as the concretization of moral life flowing from faith. "By faith, love, and grace, a community, a community of Christ - a Church in which responsibility for received faith and experienced love is born. Responsibility for the faith and love of others is also born. Through faith and love, we become able to confess Christ to people and social love."72 "Thus: if a man were aware that the essence of the whole matter is to love his neighbor as himself, it would be easier to improve mutual relations, establish the principles of distributive, social, or any other justice. The law of love and its specificity-social justice-are inspired by Christian hope." ${ }^{, 73}$

\section{CONCLUSIONS}

Summing up, it is necessary to evaluate the undoubted sense of (post) modernist concepts for contemporary theological discourse. In listing some crucial problems, it is important to highlight those aspects by which personalism can and should take into account postmodern thought. Perhaps most importantly, (post) modernity manifests a sense of openness to the unknown

kości o obecność Kościoła w świecie współczesnym. Warszawa 18.04.1973.” In Stefan WySZYŃSKI. „Idzie nowych ludzi plemię...” (Poznań, Warszawa: Pallottinum, 1973), 93; Adam RodziŃSKI, Osoba i kultura (Warszawa: Ośrodek Dokumentacji i Studiów Społecznych, 1985), 29-31.

${ }^{71}$ Stefan WYSZYŃSKI, "Kamienie węgielne budowania na górach świętych. Na Jasnej Górze po powrocie z uwięzienia, 2.11.1956," in WYSZYŃSKI. Nauczanie społeczne 1946-1981, 64.

${ }^{72}$ IDEM, "Jakiej chcecie Polski? Do młodzieży akademickiej w Warszawie 22.03.1972," in WYSZYŃSKI, Nauczanie społeczne 1946-1981, 490.

${ }^{73}$ WysZYŃSKI, “Naród-Kościót-państwo, Kazanie świętokrzyskie 25.01.1976,” 707. 
and the "Other," as well as undermines claims about absolute truth contained in closed philosophical-theological systems. In this sense, it also requires listening to other narratives, given the historical context.

(Post) modernity also obliges traditional theology to "not rationalize," awakening modern man to the "Otherness of God," saving him from rationalism and theological Cartesianism. It also helps modern men live with chance and differences, correcting provincial monism and warning against losing clarity. (Post) modernism warns us against straightforward claims about the divine and natural law; warns against systemic distortions, ideologies, and pathologies - sensitizes to the fact that-often genuine-passion for learning about religious truth often turns into narrow dogmatism. Therefore, (post) modernism reveals the shallowness of thinking about identity and uniformity; it exposes the economic and cultural foundations and prejudices regarding all theoretical formulas, which in practice turn out to be inadequate.

At the same time, postmodernity itself is understood as a kind of concept characterized by a "holistic" and systematic view of cultural reality. As a result, the questions it raises seem quite clear: does the broadly understood rejection of universal and basic principles create communication hindrances? Does the paradigm indicated by postmodernism undermine the theoretical foundations of liberal democracy? Is not Western European democratic tradition based on unwavering axioms about nature, truth, and personality? Can such a language be dismissed as mere conceptual homogeneity based on the naivety of the Enlightenment? If this kind of paradigm is to be rejected, then based on what rationale should modern man continue the discourse on contemporary pluralist Christian culture?

Though the main theological questions are more relevant to the above discussion, the most important of these is the concept of revelation and the theological claim of an ontology appropriate to revelation. All the issues discussed above ultimately concern this subject. It is a stable genius of Heidegger that he saw the absolute centrality of this fundamental issue. From the very beginning, he realized that a change in philosophical optics could only be initiated by a radical deconstruction of tradition, a new "fundamental ontology."

However, the theologically neuralgic question is this: is a postmodernist deconstruction of classical ontology-given its nonfoundationalist turn and the pulsating implications this has for truth, hermeneutics, and allied issues - revelationally appropriate? In other words, can it clarify, sustain, and 
illuminate the theology of revelation undergirding the Catholic Church? It is not revelationally applicable in any ultimate and final way if revelation is understood in the classical sense of a locutio Dei that is, in some substantive manner, continuous, identical, perpetual, universal, and self-same. Traditionally, there is a material continuity of faith and belief, classically denominated the deposit of faith that survives from age to age.

Thus understood, "eternity" is an ambiguous concept, but it also includes an element of constancy and immutability. Ultimately, it fits in with the theological ideas of "adequacy," "correspondence," and "analogy," which is supported by the concern for the proper use of reconstructive hermeneutics. If revelation then means that there is an identity of fundamental affirmations passed down from generation to generation, then Heidegger's approach is unacceptable because it only cannot sustain that kind of interpretation.

On the other hand, it is legitimate and essential to invert the question: does tradition provide an ontologically correct understanding of revelation? A particular version of revelation - with its real, hermeneutic, and linguistic implications - would have to be abandoned if it were found to be unquestionably philosophically unsustainable. No view of revelation, however deeply rooted in tradition, can ultimately hold if it is rationally unacceptable. Thus, the question now being asked in various disciplines-literary criticism, philosophy of science, cultural anthropology, and critical legal studiesmust necessarily be directed to theology: Can the traditional understanding of revelation - with its consequences of truth, hermeneutics, and the specificity of language - now be associated with the "discredited" and simplified ontology? Or should theology not correctly adapt to Heidegger's intuition and postmodernity?

These questions are answered by a Catholic intermingling of faith and reason as well as a genuine understanding of their correlation. Of course, several theologians have already come to the conclusion that traditional ontology and the theses associated with it are wrong, that it is necessary to rethink the whole tradition to face this new situation honestly. If a classical ontology is currently inappropriate, leading to difficult-to-resolve aporia in the face of radical historicity, then one must seek an understanding of revelation that fits and corresponds to the newly formed ontology.

Of course, it is true that if revelation is resistant to all kinds of non-fundamentalistic ontology. It is our understanding of it that must become highly epiphany and dialectical. Many scholars argue that revelation should be understood as changing, not only in the form (the progress already demanded 
by history) but even in its primary content. In this case, the revelation has an "old age" characteristic of Being itself. In other words, the revelation was created following the postmodern notion of the event, with its constant oscillation between presence and absence. Even if there are material contradictions between the ages, they should not be understood pejoratively, but as the newly revealed and undefined character of being and truth.

What persists in the Church is not merely the same content maintained from generation to generation, even if it is a multidimensional and theologically profound matter. The message of theological tradition is expressed in what has survived. It is a Christian reflection on the same texts, symbols, and meanings that have been transmitted in the community and which still claim to be the fundamental content of the faith. Of course, interpretations of texts will (and must) vary considerably depending on age and cultural context. However, the texts themselves should be ascribed a certain normativity, understood as a testimony to the original event. But understanding them will always reflect the different and impassable forms of life. On the other hand, changes in interpretation and meaning will reflect the inexorable fluctuation of historicity and changeability characteristic of the history of all humanity, including the Christian community.

Catholic theology has taken over a lot from postmodernity and will continue to do so. Our theology has rightly become post-rationalist, post-Enlightenment, and post-positivist. The March of Catholic thought in the $21^{\text {st }}$ century adopted the principles of historical and ideological sensitivity. Thus, Catholic theology abandoned naive and rigid referentialism, rejected the specter of "pure" conceptualism, accepted the difficulties accompanying hermeneutical issues, as well as activated the apophatism inherent in understanding the divine, recognizing not only the cataphatic discourse (i.e., having God's features as its object) as non-factual but also questioning the cognitive value of theology and philosophy built on the negation of His specific qualities.

Many modern theologians see these changes not so much as reluctant concessions but as ontologically enriching and useful achievements in theological discourse, especially in the context of contemporary Christian culture. At the same time, many questions remain: can Catholic theology avoid referentialism traditionally associated with its understanding of the mysteries of faith without revealing its identity? Can you think of the metaphysics that underlies the logic of realism, presence, and continuity? 
The answers to these questions force a departure from-narrowly understood-(post) modernity and its non-foundationalism in favor of a historically and ideologically sophisticated Christian foundationalism inscribed in return to the sources of faith. The above suggestion seems to be a correct alternative to (post) modernity. It does not, however, consist of a simple return to ontotheology but is an attempt to understand faith in a broad framework of both tradition and contemporary philosophical and theological thought concerning fundamental issues of Christian culture.

\section{BIBLIOGRAPHY}

Ambrozic, Aloysius. "Dialogue with Secularism." Culture and Faith. Pontificium Consilium de Cultura, 2000.

BARTnik, Czesław. “Zarys myśli teologicznej Kardynała Wyszyńskiego.” Ateneum Kapłańskie 73 (1981), vol. 97: 225-226.

Baudrillard, Jean. Consumer Society: Myths and Structures. London: Sage Publications, 1998.

Bauman, Zygmunt. Etyka ponowoczesna. Translated by Janina Bauman \& Joanna Tokarska-Bakir. Warszawa: Wydawnictwo Naukowe PWN, 1996.

Bauman, Zygmunt. Wieloznaczność nowoczesna i nowoczesność wieloznaczna. Translated by Janina Bauman, revised by Zygmunt Bauman. Warszawa: Wydawnictwo Naukowe PWN, 1995.

Bell, Daniel. The Coming of Post-Industrial Society: A Venture in Social Forecasting. New York: Basic Books, 1973.

Blumenberg, Hans. The Legitimacy of the Modern Age (Studies in Contemporary German Social Thought). Translated by Robert M. Wallace. Cambridge, MA: MIT Press, 1983.

Bonsor, Jack A. "History, Dogma, and Nature: Further Reflections on Postmodernism and Theology." Theological Studies 55, no. 2 (1994): 295-313. DOI: 10.1177/0040563994055 00206.

Calinescu, Matei. Five Faces of Modernity: Modernism, Avant-Garde, Decadence, Kitsch, and Postmodernism. Durham, NC: Duke University Press, 1987.

CAPUTO, John. "Gadamer's Closet Essentialism: A Derridean Critique.” In Dialogue and Deconstruction: The Gadamer-Derrida Encounter, edited by Diane P. Michelfelder \& Richard E. Palmer, 258-264. Albany: State University of New York Press, 1989.

CeleJ, Jan Zbigniew. Kultura chrześcijańska dusza narodu. Warszawa: Wydawnictwo Sióstr Loretanek, 1995

Cremonini, Annamaria. Giacomo Lercaro e il suo magistero sociale. Bologna: Conquiste, 2002.

Dulles, Avery. The Craft of Theology. New York: Crossroad, 1992.

Dunne, Joseph. Back to the Rough Ground: 'Phronesis' and 'Techne' in Modern Philosophy and in Aristotle. Notre Dame: University of Notre Dame, 1993.

FEL, Stanisław, \& Marek WódKA (eds.). Kardynat Stefan Wyszyński (1901-1981). Myśl spoteczna. Lublin: Wydawnictwo KUL, 2017.

FICEK, Ryszard. Christians in Socio-Political Life: An Applied Analysis of the Theological Anthropology of Cardinal Stefan Wyszyński, Primate of Poland. Torun: Wydawnictwo Adam Marszałek, 2020.

FritZe, Ronald H. New Worlds: The Great Voyages of Discovery 1400-1600. London, Westport, CT: The History Press, 2002. 
Funkenstein, Amos. Theology and the Scientific Imagination from the Middle Ages to the Seventeenth Century. Princeton, NJ: Princeton University Press, 1986.

Gadamer, Hans-Georg. Truth and Method. Continuum, New York: 1993.

GiERYCZ, Michał. "Przejawy instrumentalizacji religii w polskiej polityce." In Ile Kościoła w polityce, ile polityki w Kościele, edited by Piotr Burgoński, Józef Kupny, \& Sławomir Sowiński, 179-203. Katowice: Księgarnia św. Jacka, 2009.

Gregory XVI. Encyclical Mirari Vos (1832). In The Papal Encyclicals 1740-1878, edited by Claudia Carlen, 235-243. Ann Arbor, MI: Pierian, 1990.

Habermas, Jürgen. "Modernizm - niedopełniony projekt." Translated by Adam Sobota. Odra 1987, nr 7-8: 45-53.

Harris, Sam. The Moral Landscape: How Science Can Determine Human Values. New York: Free Press, 2010.

Henrici, Peter. "Modernity and Christianity." Communio 17 (1990), no. 3: 141-152.

Hoy, David Couzens. "Heidegger and the Hermeneutic Turn." In The Cambridge Companion to Heidegger, edited by Charles Guignon, 161-187. Cambridge: Cambridge University Press, 1993.

Huyssen, Andreas. After the Great Divide: Modernism, Mass Culture, Postmodernism. New York: Macmillan, 1988.

KASPER, Walter. Faith and the Future. London: Burns \& Oates, 1985.

KASPER, Walter. Theology and Church. Translated by M. Kohl. New York: Crossroad, 1992.

KiereŚ, Henryk. "Postmodernizm: rzeczywistość czy kreacja." In Poznanie bytów, czy ustalenie sensów? Zadania współczesnej metafizyki 1, edited by Andrzej Maryniarczyk \& Maria Joanna Gądek, 175-190. Lublin: Polskie Towarzystwo Tomasza z Akwinu, 2016.

Kowalczyk, Stanisław. "Etyka postmodernizmu." Idō - Ruch dla Kultury 4 (2004): 333-339.

KowALSKA, Joanna. "Kardynał Wyszyński w walce o człowieka sumienia.” Społeczeństwo 26 (2016), no. 3: 131-136.

Latour, Bruno. We Have Never Been Modern. Cambridge, MA: Harvard University Press, 1993.

Leo XIII. Encyclical Inscrutabili Dei Consilio (1878). In Actes de Leon XllI. Vol. I, 8-25. Paris: Maison de la Bonne Presse, 1903.

Leo XIII. Encyclical Nobilissima Gallorum Gens (1884). In Actes de Leon XIII. Vol. II, 54-71. Paris: Maison de la Bonne Presse, 1903.

Leo XIII. Encyclical Quod Apostolica Muneris (1878). In Actes de Leon XllI. Vol. I, 26-41. Paris: Maison de la Bonne Presse, 1903.

"List Episkopatu Polski do duchowieństwa o moralnym zagrożeniu narodu. Warszawa 25 I 1968." In Listy Pasterskie Episkopatu Polski 1945-1974, 506-509. Paris: Editions du Dialogue, 1975.

Lonergan, Bernard. Doctrinal Pluralism. Milwaukee, WI: Marquette University Press, 1971.

Lonergan, Bernard. Method in Theology. London: Longman and Todd, 1971.

Luchte, James. Kant's Critique of Pure Reason: A Reader's Guide. London, New York: Continuum, 2007.

"Memoriał Episkopatu polski do rządu PRL w sprawie zagrożeń biologicznych i moralnych Narodu Polskiego. (1970)." In Prymas Polski w obronie życia nienarodzonych, cz. II, Prymas Polski w obronie życia nienarodzonych. Cz. II, 305-306. Warszawa: Ośrodek Dokumentacji i Studiów Społeczntch, 1982.

Mizrahi, Moti. "What's So Bad About Scientism?” Social Epistemology 31 (2017), no. 4: 351-367.

PAlmer, Richard E. Hermeneutics. Interpretation Theory in Schleiermacher, Dilthey, Heidegger, and Gadamer. Evanston, IL: Northwestern University Press, 1969. 
PIus IX. Encyclical Qui Pluribus (1846). In The Papal Encyclicals 1740-1878, 275-277. New York: McGrath, 1981.

Pius VI. Encyclical Charitas (1791). In The Papal Encyclicals 1740-1878, 177-178. New York: McGrath, 1981.

Platt, David. Counter Culture, Following Christ in an Anti-Christian Age. New York: Tyndale House Publishers, Inc, 2017.

RAHner Karl, \& Edward Quinn. “Mysterium Ecclesiae.” Cross Currents 23 (1973), no. 2, 183-198.

RodziŃSKI, Adam. Osoba i kultura. Warszawa: Ośrodek Dokumentacji i Studiów Społecznych, 1985.

RoRTy, Richard. Filozofia a zwierciadto natury. Translated by Michał Szczubialko. Warszawa: Wydawnictwo Spacja, 1994.

Rorty, Richard. Objectivity, Relativism and Truth. Philosophical Papers. Cambridge, MA: Cambridge University Press, 1991.

Rosık, Seweryn. "Promocja aksjologicznej pozycji osoby ludzkiej i wspólnoty rodzinnej niektórych dziełach Kardynała Stefana Wyszyńskiego.” Roczniki Teologiczne 38-39 (19911992), issue 3: 83-103.

Skorowski, Henryk. Problematyka praw człowieka: Stadium z nauki społecznej Kościoła. Warszawa: Akademia Teologii Katolickiej, 1996.

Weber, Max. Nauka jako zawód i powolanie. Translated by Piotr Egel. In Max Weber, Polityka jako zawód i powołanie, wybrał, opracował i wstępem opatrzył [selected, compiled and edited with an introduction by] Marek Dębski, 111-140. Warszawa: Niezależna Oficyna Wydawnicza, 1989.

Woods, Thomas E. How the Catholic Church Built Western Civilization. Washington, DC: Regnery, 2005

WysZYŃSKI, Stefan. “«Homo Dei». I kazanie świętokrzyskie 13 I 1974.” In Stefan WyszyŃsKI. Nauczanie społeczne 1946-1981, 574-580. Warszawa: Ośrodek Dokumentacji i Studiów Społecznych, 1999.

WYsZYŃSKI, Stefan. “«Jasnogórskie zobowiązania...». Bydgoszcz, 19.12.1956.” In Kazania i przemówienia autoryzowane 1956-1981. Vol. 1-67, vol. 1, 302-307. Warszawa: Archiwum Instytutu Prymasowskiego w Warszawie, 1956-1981.

WYSZYŃSKI, Stefan. "Do «Solidarności» wiejskiej rolników indywidualnych. Warszawa-Miodowa 2.02.1981. In Stefan WyszyŃSki. Do „Solidarności.” Rady i wskazania, 78-89. Warszawa: Oficyna Naukowa, 1996.

WyszYŃski, Stefan. "Dobrzy bracia. Podczas uroczystości 250 rocznicy bonifratrów do Warszawy 26 IX 1976.” In Stefan WYSZYŃSKI. Nauczanie społeczne 1946-1981, 747-751. Warszawa: Ośrodek Dokumentacji i Studiów Społecznych, 1999.

WysZyŃski, Stefan. "Jakiej chcecie Polski? Do młodzieży akademickiej w Warszawie 22. 03. 1972.” In Stefan WYSZYŃSKI. Nauczanie społeczne 1946-1981, 488-493. Warszawa: Ośrodek Dokumentacji i Studiów Społecznych, 1999.

WyszyŃSKi, Stefan. "Kamienie węgielne budowania na górach świętych. Na Jasnej Górze po powrocie z uwięzienia, 2.11.1956." In Stefan WYSZYŃSKI. Nauczanie społeczne 1946-1981, 62-67. Warszawa: Ośrodek Dokumentacji i Studiów Społecznych, 1999.

WysZyŃski, Stefan. Miłość i sprawiedliwość społeczna. Poznań: Pallottinum, 1993.

WysZYŃSKI, Stefan. "Moc żywej wiary w ciężkiej sytuacji Kościoła. Do duchowieństwa w Gdańsku, 23.11.1960.” In Stefan WYSZYŃSKI. Nauczanie spoleczne 1946-1981, 161-167. Warszawa: Ośrodek Dokumentacji i Studiów Społecznych, 1999.

WyszyŃski, Stefan. "Naród-Kościót-państwo, Kazanie świętokrzyskie 25.01.1976." In Stefan WYSZYŃSKI. Nauczanie spoleczne 1946-1981, 705-713. Warszawa: Ośrodek Dokumentacji i Studiów Społecznych, 1999. 
WYSZYŃSki, Stefan. "Nasze dezyderaty. Do profesorów katolickiej nauki społecznej, Jasna Góra 22 I 1963.” In Stefan WYsZYŃSKI. Nauczanie społeczne 1946-1981, 195-200. Warszawa: Ośrodek Dokumentacji i Studiów Społecznych, 1999.

WYSZYŃSKI, Stefan. "O chrześcijańskim wyzwoleniu człowieka. List pasterski na adwent 1946." In Stefan WYSZYŃSKI. Nauczanie spoteczne 1946-1981, 14-28. Warszawa: Ośrodek Dokumentacji i Studiów Społecznych, 1999.

WYSZYŃSKI, Stefan. “O katolickiej woli życia. List pasterski na Wielkanoc 1947.” In Stefan WySZYŃSKI. Nauczanie społeczne 1946-1981, 29-40. Warszawa: Ośrodek Dokumentacji i Studiów Społecznych, 1999.

WyszyŃski, Stefan. "O pokoju na ziemi: Po ogłoszeniu encykliki «Pacem in terris». Białystok 2. 06.1963.” In Stefan WYSZYŃSKI. Nauczanie społeczne 1946-1981, 212-215. Warszawa: Ośrodek Dokumentacji i Studiów Społecznych, 1999.

WYSZYŃSKI, Stefan. "O zagrożeniu moralności narodu. List pasterski na Wielki Post 1968." In Stefan WysZYŃSKI. Nauczanie społeczne 1946-1981, 343-352. Warszawa: Ośrodek Dokumentacji i Studiów Społecznych, 1999.

WysZYŃSki, Stefan. "Ojcze nasz. Do Instytutu Prymasowskiego podczas rekolekcji. Warszawa 48.12.1961.” In Kazania i przemówienia autoryzowane 1956-1981. Vol. 1-67. Archiwum Instytutu Prymasowskiego w Warszawie. Vol. 19, 312-436.

WysZyŃski, Stefan. "Problem pracy górników w Polsce. List do księdza biskupa Herberta Bednorza, 2.02.1978." In Stefan WysZYŃSKI. Nauczanie społeczne 1946-1981, 810-811. Warszawa: Ośrodek Dokumentacji i Studiów Społecznych, 1999.

WyszyŃski, Stefan. "Przemówienie w Boże Narodzenie w archikatedrze św. Jana Chrzciciela. Warszawa, 25 XII 1978.” In Prymas Tysiaclecia, edited by Florian Kniotek, 274-275. Edition du Dialogue, Paryż 1982.

WYSZYŃSki, Stefan. “To jest nasz program prymasowski. Do wiernych w bazylice prymasowskiej w Gnieźnie 2 II 1957.” In Stefan WyszyŃSKI. Nauczanie społeczne 1946-1981, 74-77. Warszawa: Ośrodek Dokumentacji i Studiów Społecznych, 1999.

WyszyŃski, Stefan. “W godzinie wielkiego rachunku sumienia. Ołtarzew 2.10.1980.” In Kościót w stużbie Narodu. Nauczanie Prymasa Polski czasu odnowy w Polsce sierpień 1980maj 1981, 73-77. Rzym: Ośrodek «Corda Cordi» i Delegatury Biura Prasowego Episkopatu Polski w Rzymie, 1981.

WYsZYŃSKI, Stefan. "W obronie religii Chrystusowej i bezpieczeństwa ojczyzny. Podczas uroczystości Królowej Polski na Jasnej Górze 3.05.1973.” In Stefan WysZYŃSKI. Nauczanie społeczne 1946-1981, 547-549. Warszawa: Ośrodek Dokumentacji i Studiów Społecznych, 1999.

WysZyŃSKi, Stefan. “W obronie życia Polaków. Warszawa-Leszno 9.03.1975.” In. Stefan WySZYŃSKI. Prymat człowieka w ładzie społecznym, 184-188. Londyn: Odnowa, 1976.

WYSZYŃSki, Stefan. "Wołanie ludzkości o obecność Kościoła w świecie współczesnym. Warszawa 18.04.1973.” In Stefan Wyszyński. „Idzie nowych ludzi plemię...,” 91-98. Poznań, Warszawa: Pallottinum, 1973.

WyszyŃski, Stefan. “Zło dobrem zwyciężaj. Do „Solidarności“ z Gdyni. Warszawa, Kaplica Domu Prymasowskiego, 22 II 1981.” In Do „Solidarności“. Rady i wskazania, 63-70. Warszawa: Soli Deo, 1996.

WysZYŃski, Stefan. "Zwycięstwo wiary naszej. Do duchowieństwa Warszawy 24 XII 1973.” In Stefan WYSZYŃSKI. Nauczanie społeczne 1946-1981, 570-573. Warszawa: Ośrodek Dokumentacji i Studiów Społecznych, 1999. 


\section{(POST-) MODERNITY AND CHRISTIAN CULTURE \\ IN THE CONTEXT OF THE PERSONALISM OF CARDINAL STEFAN WYSZYŃSKI}

\section{$\mathrm{Sum}$ m a ry}

Need to indent here, a rough analysis of the situation in the world is enough to realize the here and throughout modern Christianity, as well as the foundation on which today's culture of the Western world is based. No wonder that many Christian intellectuals view it as multidimensional, highly complex, with sometimes bothersome and destructive symptoms. Undoubtedly, the Christian roots of cultural reality related primarily to Europe are correlated with the birth of the modern idea of scientific rationality, which brought humanity great opportunities, but also serious threats.

Thanks to the idea of rationality, Europe has developed a culture that, especially now - in a way previously utterly unknown to humankind - is trying to exclude God from the sphere of public consciousness. Of course, the existence of God can be denied entirely or made it impossible to prove, assuming that - faith or nonbelief - it is a matter of purely subjective choice. Nevertheless, in both cases, in the opinion of many modern ideologies of (post-) modernity, God should not be of significant importance to the whole reality of public life.

Thus, presenting the role of anti-Catholicism in the classical approach to (post-) modernity, as well as the tradition of Catholic anti-modernism, will allow for a more constructive display of the spirit of the conciliar aggiornamento, which is unfortunately related to the more general crisis of contemporary times of the 1970s and 1990s. It was during this period that one could notice both a retreat from "modernity" as a concept that "sensitizes" the paradigm of the cultural reality of that time, and "postmodern" religious revival understood as a challenge to articulate a living Christian tradition inscribed in the global complexity of the contemporary world. Contrary to the temptation to isolate oneself from external influences, and therefore the awakening cognitive dissonance, aspects of the current paradigm of (post-) modern reality may be essential and useful in shaping a constructive dialogue with the contemporary world, as well as in promoting Catholic culture that forms the identity of Christianity today.

Therefore, the main aim of the above article is to display the fundamental issues concerning (post-) modernity and how they influence significant theological problems, especially in the context of the personalistic vision presented by Cardinal Stefan Wyszyński. It applies primarily to such vital matters as the problem of truth, hermeneutics, the specificity of a functional language, and their mutual correlation. In this sense, contemporary theological discourse can be significantly enriched by taking into account many aspects of contemporary postmodern theory, especially concerning culture. An essential condition for this, however, is to take into account the undoubted achievements of previous epochs. However, the fundamental task of Christians is to create the reality of authentically humanistic culture, capable of shaping the human person under his vocation. It is possible due to the sphere of personal and social values which, in forming man, condition the transformation of the entire cultural reality of the world from the perspective of "new heaven and a new earth" (cf. 2 Pt 3:13; Rev 21:1).

Key words: Cardinal Stefan Wyszyński; Second Vatican Council; culture; modernism; postmodernism; post-Enlightenment tradition; personalism. 


\section{(POST) MODERNIZM I KULTURA CHRZEŚCIJAŃSKA W KONTEKŚCIE PERSONALIZMU KARDYNAŁA STEFANA WYSZYŃSKIEGO}

\section{Streszczenie}

Wystarczy pobieżna analiza sytuacji na świecie, aby zweryfikować kulturowy kontekst współczesnego chrześcijaństwa, jak również fundamenty, na których opiera się dzisiejsza kultura świata Zachodu. Nic więc dziwnego, że wielu chrześcijańskich intelektualistów ocenia ją jako wielowymiarową, wysoce skomplikowaną, przejawiającą niekiedy bardzo niepokojące destruktywne symptomy. Niewątpliwie, chrześcijańskie korzenie rzeczywistości kulturowej związane przede wszystkim z Europą są skorelowane $\mathrm{z}$ narodzinami nowoczesnej idei naukowej racjonalności, która przyniosła ludzkości wielkie możliwości, ale także poważne zagrożenia.

Dzięki idei racjonalności, Europa rozwinęła kulturę, która szczególnie teraz — w sposób wcześniej zupełnie nieznany ludzkości — próbuje wykluczyć Boga ze sfery świadomości publicznej. Oczywiście istnieniu Boga można całkowicie zaprzeczyć lub uznać za niemożliwe do udowodnienia, zakładając, że - wiara lub niewiara - jest to kwestia wyłącznie subiektywnego wyboru. Niemniej jednak, w obu przypadkach—zdaniem wielu współczesnych przedstawicieli (post)nowoczesności - Bóg nie powinien mieć istotnego znaczenia dla całości życia publicznego.

Ukazanie zatem roli antykatolicyzmu w klasycznym ujęciu (post) nowoczesności, a także tradycji katolickiego antymodernizmu, pozwoli na bardziej konstruktywne wyeksponowanie ducha soborowego aggiornamento, co niefortunnie wiąże się z bardziej ogólnym kryzysem nowoczesności w latach siedemdziesiątych i dziewięćdziesiątych XX wieku. W tym właśnie okresie można zauważyć zarówno odwrót od „nowoczesności” jako koncepcji „usensowiającej” paradygmat ówczesnej rzeczywistości kulturowej, jak i ,ponowoczesne” odrodzenie religijne rozumiane jako wyzwanie do wyartykułowania żywej chrześcijańskiej tradycji wpisanej w globalną złożoność współczesnego świata.

Głównym zatem celem powyższego artykułu jest ukazanie fundamentalnych kwestii dotyczących (post)nowoczesności i sposobowi, w jaki wpływają one na istotne kwestie teologiczne, zwłaszcza w kontekście personalistycznej wizji prezentowanej przez Kardynała Stefana Wyszyńskiego. Dotyczy to szczególnie tak ważnych zagadnień jak zagadnienie prawdy, hermeneutyki, specyfiki funkcjonującego języka i ich wzajemnych korelacji. W tym znaczeniu, współczesny dyskurs teologiczny może zostać znacznie ubogacony, uwzględniając wiele aspektów współczesnej teorii ponowoczesnej, zwłaszcza w odniesieniu do kultury. Istotnym tego warunkiem jest jednak uwzględnienie niewątpliwych osiągnięć poprzednich epok. Podstawowym jednak zadaniem chrześcijan jest kreowanie rzeczywistości kultury autentycznie humanistycznej, zdolnej do kształtowania osoby ludzkiej zgodnie z jej powołaniem. Jest to możliwe dzięki sferze wartości osobistych i społecznych które, formując człowieka, warunkują transformację całej kulturowej rzeczywistości świata w perspektywie ,nowego nieba i nowej ziemi” (por. 2 P 3,13; Ap. 21,1).

Słowa kluczowe: Kardynał Stefan Wyszyński; Sobór Watykański II; kultura; modernizm; postmodernizm; tradycja postoświeceniowa; personalizm. 